\title{
CONFERÊNCIA
}

\section{O NOVO CORONAVÍRUS, A PEDAGOGIA HISTÓRICO-CRÍTICA, A SOCIEDADE DE CLASSES E O INTERNACIONALISMO PROLETÁRIO}

\author{
Paulino José Orso ${ }^{1}$ \\ Os homens fazem sua própria história, mas \\ não a fazem sob circunstâncias de sua \\ escolha e sim sob aquelas com que se \\ defrontam diretamente [...]. (Karl Marx)
}

\section{Caráter introdutório}

Durante a brevidade de nossas vidas, já presenciamos dissemelhantes tipos de conflitos, guerras, crises econômicas, catástrofes, tragédias, golpes de estados, autoritarismo, repressão, miséria, fome, enfim, diferentes problemas sociais, políticos, econômicos e educacionais. Entretanto, jamais enfrenamos algo parecido com uma pandemia como a do novo coronavírus, pois, não se trata de um mero fenômeno conjuntural e localizado; ao contrário, atinge a escala global e se soma à profunda crise política, econômica e social já existente. Com isso, senão em profundidade, ao menos em abrangência, nos deparamos com a mais ampla crise já enfrentada pela sociedade capitalista, inclusive, maior que a do final da década de 1920 e início dos anos de 1930.

Aliás, no segundo trimestre de 2020, a economia dos Estados Unidos, a locomotiva do capitalismo mundial, contraiu no ritmo mais acentuado desde a Grande Depressão. Com isso, o Produto Interno Bruto (PIB) do país desabou, caiu $32,9 \%$ em taxa anualizada, registrando a maior queda desde que o governo começou a contabilizar os dados em 1947. Ao lado disso,

\footnotetext{
1 Doutor em História e Filosofia da Educação pela Unicamp, docente dos Cursos de Pedagogia, do Mestrado e doutorado em Educação da Unioeste, líder do Grupo de Pesquisa HISTEDOPR. Orcid iD: https://orcid.org/0000-0001-9126-3276 E-mail: paulinorso@vol.com.br
} 
nesse mesmo período, a economia da Alemanha, a maior da Europa, também despencou, caiu 10,1\% do PIB, a maior queda desde 1970.

Pela primeira vez na história, a humanidade vivencia um confinamento forçado que paralisou mais de 3,5 bilhões de pessoas, ou seja, mais da metade da população do planeta. Um fato inédito, que já entrou para a história, porém, da forma mais apavorante possível, gerando pânico, espalhando temor, provocando incertezas - certamente será lembrada por séculos, tanto por suas consequências econômicas, como humanas e sociais.

A parada forçada atingiu desde grandes metrópoles até pequenas urbes e povoados, grandes empresas nacionais e transnacionais, trabalhadores ativos e desempregados. Para alacridade do meio ambiente e dos ouvidos humanos, motores de aviões, trens, metrôs, motos, ônibus, máquinas, automóveis ..., ao menos por algum tempo, silenciaram e deixaram de expelir poluição, exceto as motosserras dos latifundiários, que aproveitaram-se de um governo permissivo para promover mais estragos e destruição, especialmente na Amazônia. A produção e o consumo de combustíveis sofreram uma redução drástica, os estoques saturaram, e as gigantes mundiais do petróleo entraram em crise. O comércio, a indústria, os restaurantes ... fecharam suas portas. O Produto Interno Bruto (PIB) global despencou. Os pastores lacraram as portas de seus templos, deixaram de reunir multidões e promover seções de cura, descarrego e "milagres". A energia vibrante e juvenil do interior das escolas, cedeu lugar à calmaria e ao silêncio. As ruas apinhadas de transeuntes, transformaram-se em verdadeiros desertos humanos. A impressão é a de "um mundo sem ninguém". Nunca nos defrontamos com algo dessa dimensão e com tal magnitude, o mundo parece ter sido posto de cabeça para baixo.

Mesmo sem o coronavírus, já eram fartos os problemas com os quais nos debatíamos e tínhamos que enfrentar e resolver... afinal, o capital não dá tréguas... Apesar disso, o novo coronavírus não teve clemência, nos "presenteou" com mais uma infinidade de novos problemas, causando uma 
sensação de apreensão, inquietação, espanto, assombro, preocupação e pânico em todo o mundo.

O coronavírus não faz distinção de sexo, tamanho, cor, raça, classe social, local de origem e habitação... Ele é implacável com as populações mais carentes, cujo os governos são negligentes, insensíveis, negam a ciência e tem como única preocupação o capital e o lucro. Assim, os impactos sobre a vida social se multiplicam, serão praticamente impossíveis de se dimensionar e calcular. Sem contar o cinismo dos governos, empresários e latifundiários inescrupulosos que se aproveitam do estado de calamidade para realizar mais mudanças, ampliar os ataques à classe trabalhadora, colocara "granada no bolso do inimigo", "passar a boiada" $2 \mathrm{e}$ aumentar a acumulação.

A despeito disso, creio que o leitor esteja um tanto surpreso e atônito com o título deste artigo "O novo coronavírus, a pedagogia histórico-crítica, a sociedade de classes e o internacionalismo proletário", e se perguntando, o que tem a ver uma coisa com outra? Afinal, estamos falando de um vírus descoberto em 31/12/193, na China, que desencadeou a pandemia da COVID-19, é extremamente agressivo, causa infecções respiratórias e, em muitos casos, leva a morte.

A surpresa, porém, talvez fique por conta de quem pensa a educação de modo abstrato e descontextualizado, como se ocorresse de forma isolada e independente da sociedade, ou de quem desconhece a Pedagogia Histórico-Crítica e sua proposta pedagógica. Todavia, não dá para se discutir e nem compreender a educação e a sociedade disjuntas. Elas são indissociáveis. Como não estamos sós e isolados; como vivemos em

\footnotetext{
${ }^{2}$ Expressões utilizadas respectivamente pelos ministros Paulo Guedes (economia) e Ricardo Salles (meio ambiente), em reunião ministerial ocorrida no dia 22 de maio, no Palácio do Planalto, expressando que o governo deveria aproveitar o isolamento social devodp à pandemia, enquanto a grande maioria está preocupada com a Covid-19, para atacar os trabalhadores, retirar direitos e beneficiar latifundiários e agropecuaristas.

3 A sars-cov-2, vírus que causa a COVID-19, é um vírus novo, do mesmo grupo do coronavírus, identificado pela primeira vez em 1937, pela pesquisadora escocesa June Almeida (1930-2007), em 1964, em seu laboratório no hospital St. Thomas, em Londres. (BBC. NEWS. Brasil, 2020). Somente em 1965, foi descrito como coronavírus, em decorrência do perfil na microscopia, assemelhando-se a uma coroa.
} 
sociedade, precisamos educar e nos educar. A vida em sociedade pressupõe a educação, a preparação dos indivíduos para viverem nela mesma. (ORSO, 2019, p. 316). Assim, cabe à educação, na perspectiva da PHC, identificar os problemas postos pela realidade, mediar sua superação, preservar a vida e construir uma nova humanidade.

Por conseguinte, não é possível pensar a educação e, em especial, a educação na perspectiva da PHC, sem considerar a sociedade e a realidade existente. De acordo com Saviani, a Pedagogia Histórico-Crítica "entende que a educação se relaciona dialeticamente com a sociedade". (SAVIANI, 1999, p. 75).

Contudo, os tempos de crise também se prestam para a reflexão, o estudo, a pesquisa e busca de saídas. Assim, considerando a forma de organização e funcionamento da sociedade e a magnitude dos desafios enfrentados, tendo como referência a Pedagogia Histórico-Crítica, cabe-nos realizar uma profunda análise, objetivando a superação dos problemas com os quais nos deparamos. Pois, caso fizermos mais do mesmo, não só teremos mais do mesmo, como os problemas certamente se intensificarão.

\section{O novo coronavírus e os desafios dos trabalhadores na sociedade de classes}

A humanidade se encontra diante de um de seus maiores desafios - a defesa da vida e a preservação da espécie. Os ataques, porém, partem de diferentes inimigos. Identificá-los, compreender o tamanho das ameaças, traçar estratégias e, utilizar as armas de defesa adequadas são condições sine qua non para garantir a vida e a felicidade. Sim, apesar das circunstâncias, por que não falar da felicidade? Afinal, ao menos para a classe trabalhadora, com a COVID-19 ou sem ela, parece que foi amordaçada e proibida de falar em felicidade e, muito mais, de ser feliz.

Desde seu surgimento, a humanidade se deparou e teve que superar uma infinidade de desafios simplesmente para se manter viva, desde a luta contra animais nocivos, as intempéries e calamidades ambientais, as lutas e disputas pessoais e de classes, as guerras e doenças, as epidemias e 
pandemias devastadoras... Isso significa que, por mais perigoso que 0 coronavírus possa ser, é apenas um dos inimigos que ameaçam a classe trabalhadora.

Mas, a despeito de tudo, a humanidade tem sobrevivido, ao menos até o momento... Entretanto, encontra-se diante de um contexto crucial, travando uma batalha dura, uma guerra (de tipo não convencional), sofrendo um duplo ataque, ambos extremamente nocivos, do capital e do coronavírus. Aliás, não se sabe exatamente qual dos dois é mais perigoso e ameaçador. De qualquer modo, tanto um quanto o outro, constituem-se em parasitas que só sobrevivem à custa de seus hospedeiros. Enquanto o coronavírus depende de uma célula hospedeira para se reproduzir e se perpetuar, o capital depende do trabalhador, só sobrevive à custa de seu sangue, de sua exploração, da extração e da expropriação da mais valia.

Como nos diz Karl Marx, para o trabalhador,

\begin{abstract}
A execução do trabalho aparece tanto como uma perversão que o trabalhador se perverte até o ponto de passar fome. A objetificação aparece tanto como uma perda do objeto que o trabalhador é despojado das coisas mais essenciais não só da vida, mas também do trabalho. O próprio trabalho transforma-se em um objeto que ele só pode adquirir com tremendo esforço e com interrupções imprevisíveis. A apropriação do objeto aparece como alienação a tal ponto que quanto mais objetos o trabalhador produz tanto menos pode possuir e tanto mais fica dominado pelo seu produto, o capital. (MARX, I, 2020).
\end{abstract}

Portanto, o capital é tão ou mais infausto e perverso que o coronavírus. Veja que não estamos nos referindo a um vírus qualquer, desprezível. Ao contrário, trata-se de um ser invisível, poderosíssimo, com elevada capacidade de contágio, propagação e disseminação, um vírus de tipo corona, o SARS-2, como é denominado o novo coronavírus, o mais desenvolvido até o momento, mais hábil e resistente, uma mutação do SARS1, que provoca a Covid-19, para a qual, até a descoberta de medicamentos e de vacina adequada, o melhor antídoto é o isolamento social. É extremamente agressivo, capaz de provocar uma pandemia em escala global, com um altíssimo índice de letalidade. 
Porém, além da Covid-19, o vírus também pode provocar outra grave doença, a Síndrome Inflamatória Multisistêmica Infantil (MIS-C), que atinge crianças e adolescentes, ocasiona problemas inflamatórios, renais, neurológicos, cardíacos e dermatológicos.

Segundo o diretor-geral da Organização Mundial da Saúde (OMS), Tedros Adhanom Ghebreyesus, "A pandemia do novo coronavírus (Sars-CoV2) é 10 vezes mais letal do que o vírus responsável pela gripe $A(H 1 N 1)$, surgido entre 2009 e 2010 e que causou a morte de 18 mil pessoas em todo o mundo". (ISTO É, 2020). O número de mortos pela COVID-19 comprova essa afirmação4.

Como se trata de um vírus novo, uma mutação, que surgiu de "surpresa", os medicamentos existentes não dão conta de combatê-lo de forma acertada, pois, foram produzidos para enfrentar e resolver outros males que nos encalçam a mais tempo. Por isso, a utilização de alguns deles para tratar dos males sistêmicos provocados pelo coronavírus ocorre de forma imprópria. Esses medicamentos ainda carecem de muitos estudos, pesquisas e testagens.

\section{O conhecimento e a ciência a serviço da vida, o negacionismo a serviço da dominação e da morte.}

Daí, diante da gravidade da pandemia, de um lado, os especialistas orientam o confinamento massivo como forma de evitar ou pelo menos diminuir a velocidade do contágio e da propagação da doença. Tanto a OMS quanto os infectologistas são unânimes em orientar: "Fiquem em casa!", "Isolem-se!", "Protejam-se!", "Usem máscaras!". De outro, intensificam-se os esforços de pesquisadores, profissionais da saúde e cientistas de diferentes

\footnotetext{
4 Por ser um número que muda muito rápido, colocamos a informação em nota de roda pé. No momento em que estamos fazendo a revisão deste artigo, no dia 22 de julho de 2020, só o Brasil já registrava 2.166.532 casos confirmados e 81.597 mortos, isto é, 4,5 vezes mais do que as mortes causadas pela HINI. Nos Estados Unidos, o número de casos confirmados chegou a 3.970.671 e o de mortos a 144.173. No mundo, o número de infectados chegou a 14.951.347 e o número de óbitos já ultrapassou seis centenas, atinge a marca de 616.550 . Simplesmente assustador.
} 
áreas do conhecimento e de distintos países na busca de um antídoto apropriado para combatê-la.

Apesar de a humanidade já ter experienciado diversas pandemias, provocadas por vírus ou bactérias, tais como, Tuberculose, Varíola, Peste Bubônica, Poliomielite, Cólera, Gripe Espanhola, Gripe Asiática, Gripe de Hong Kong, Aids e HINl, de acordo com os estudiosos, a desencadeada pelo novo coronavírus, constitui-se numa das mais terríveis e ameaçadoras.

Terrível, sobretudo em função das condições dos sistemas de saúde anterior à pandemia, ao sucateamento dos mobiliários e equipamentos, à precariedade das condições de trabalho, ausência de quantitativo suficiente de pessoal e equipamentos de proteção coletiva e individual, falta de insumos necessário ao tratamento, falta de leitos suficientes à demanda das necessidades de saúde da população, entre outros problemas. Ameaçadora, pois, acomete muitos trabalhadores da saúde afastando do trabalho e, consequentemente, diminuindo o quantitativo de pessoal e aumentando em muito a sobrecarga de trabalho intensificada pelo tipo de cuidado requerido pelos doentes do novo vírus.

Diante dos perigos que enfrentamos, como não se trata de problemas individuais e localizados, como atingem o conjunto da sociedade, não seria de se esperar, portanto, que nos uníssemos e fossemos solidários, que a ciência fosse respeitada e valorizada pelos governos e pela sociedade? Afinal, dela depende a vida. Contudo, ao longo da história moderna e contemporânea, ela nunca foi tão atacada e combatida quanto no atual momento. E se intensificaram com o ascenso da extrema direita e do fundamentalismo religioso (avessos ao conhecimento), com o processo que culminou no golpe que destronou a presidente Dilma Rousseff, em agosto de 2016, e se aprofundaram, especialmente com a eleição de um presidente e um congresso ultraliberal e ultraconservador, no final de 2018, amparados pela mídia, empresários, latifundiários, militares e um judiciário da mesma natureza.

Se a democracia os permitiu chegar ao poder, uma vez consumados os fatos, julgaram que, para eles, já não era mais "necessária", foi 
condenada ao ostracismo, ou então, passou a ser entendida como sinônimo do poder e da voz dos vitoriosos. Os novos teólogos de plantão, grande parte deles, sediados no ou embalados pelo império do norte, estabeleceram novos dogmas, calaram oponentes, impuseram as suas verdades, baniram os que não eram seus iguais e os mandaram à danação. Assim, parece que chegou ao fim o mundo tal como o conhecemos ...

Como diria Marx,

Daí em diante, a luta de classes adquiriu, prática e teoricamente, formas mais definidas e ameaçadoras. Soou o dobre de finados da ciência econômica burguesa. Não interessava mais saber se este ou aquele teorema era verdadeiro ou não; mas importava saber o que, para o capital, era útil ou prejudicial, conveniente ou inconveniente, o que contrariava ou não a ordenação policial. Os pesquisadores desinteressados foram substituídos por espadachins mercenários, a investigação científica imparcial cedeu seu lugar à consciência deformada e às intenções perversas da apologética (MARX, 1968, p. 11).

Diga-se de passagem, se é que serve de consolo, ou, para o desespero dos trabalhadores, que esses ataques não são uma exclusividade brasileira, nem são desfeichados apenas pelas elites e governantes tupiniquins. Daí seu caráter ainda mais danoso, perverso e ameaçador, por ser um fenômeno generalizado, globalizado. O mundo parece não ser um lugar seguro.

Por isso, não se trata de um contrassenso, combater a ciência quando mais se necessita dela? Ou os ataques a ciência fazem parte de uma estratégia golpista, mesquinaha e macabra que, de um lado, visa submer ao extermínio de parte da população, especialmente da classe trabalhadora mais pobre, e de outro, manter os privilégios em poucas mãos?

É fácil verificar como a ciência tem sido a principal aliada do homem no que tange ao enfrentamento e resolução dos problemas sociais e humanos ao longo dos últimos 500 anos, desde que começa a se desenvolver até os dias atuais. Basta ver que, graças aos avanços científicos, sejam eles relacionados ao meio ambiente, ao melhoramento genético, à produção, ao armazenamento e conservação de alimentos e 
medicamentos, ao desenvolvimento de novas tecnologias e a produção, a expectativa de vida aumentou expressivamente.

Na Europa, em 1900, as pessoas viviam em média aproximadamente 45 anos. No continente africano, 29 anos, e no Brasil, 33,7 anos. Hoje a expectativa de vida dos europeus ultrapassa 80 anos, a dos africanos se encontra em torno de 74 anos, e a dos brasileiros, supera 76 anos. Ou seja, em pouco mais de um século, a expectativa média de vida dos africanos e brasileiros cresceu mais que o dobro.

Nesse período, não faltaram problemas e desafios. Apesar disso, num curto espaço de tempo, os brasileiros deram um salto de 145\%, aumentando mais de 42 anos a expectativa de vida. E isso deve-se a que? Ao "acaso", fortuitamente, às crenças ou crendices, a um milagre? Não. Decorreu do desenvolvimento do conhecimento, das pesquisas, da ciência e da tecnologia. Mas, a despeito de todo o desenvolvimento, dada a sociedade de classes, também aumentou extraordinariamente o número das pessoas que passam e morrem de fome.

Todavia, nos últimos anos, apesar da importância cada vez maior do conhecimento científico, a ciência tem sido duramente atacada, tanto no Brasil como no mundo. O problema é que a negação, a contestação e os ataques, não ocorrem com base em conhecimento, experiências e ciência mais desenvolvida, que poderia levar ao seu aprimoramento e, consequentemente, à melhoria das condições de vida.

Ao contrário, partem de meras especulações e fantasias, provocando uma verdadeira regressão civilizatória e humanitária. Estamos regredindo até mesmo quando se considera a perspectiva positivista. Augusto Comte (17981857) afirmava que a humanidade "inevitavelmente", ascenderia do estado teológico, ao metafísico e "descansaria" no científico, em que repousaria a razão humana.

Todas nossas especulações estão inevitavelmente sujeitas, assim no indivíduo como na espécie, a passar por três estados teóricos diferentes e sucessivos, que podem ser qualificados pelas denominações habituais de teológico, metafísico e positivo, pelo 
menos para aqueles que tiverem compreendido bem o seu sentido geral. O primeiro estado (teológico), embora seja, a princípio, a todos os respeitos, indispensável, deve ser concebido sempre, de ora em diante, como puramente provisório e preparatório; o segundo (metafísico), que é, na realidade, apenas a modificação dissolvente do anterior, não comporta mais que um simples destino transitório, para conduzir gradualmente ao terceiro (positivo); é neste, único plenamente normal, que consiste, em todos os gêneros, o regime definitivo da razão humana. (COMTE, 1976, p. 5).

Entretanto, ao invés de "descansar" no estágio científico e positivo, quando estávamos perseguindo esse patamar, numa espécie de golpe ou de salto mortal ao reverso, fomos praticamente arremessados aos primórdios da humanidade, para o estado de natureza, como se não tivéssemos "evoluído", ou pelo menos para a Idade Média, como se a modernidade tivesse sido abortada, a ciência não existisse e as explicações dos fenômenos decorressem de meras especulações, achismos e crendices.

A consequência mais trágica desse estado social é a anomia, isto é, a desintegração social e o derretimento da civilização, resultado do irracionalismo, da mesquinhez, do individualismo exacerbado, do embrutecimento, da lei do mais forte, do desrespeito e destruição das normas básicas de convivência, do desdém às diferenças, do desrespeito ao outro, da ausência de sociabilidade e do mínimo de humanidade, enfim, institui-se o estado de guerra de todos contra todos, como diria Thomas Hobbes (1588-1679).

No Brasil, os ataques, sem trégua à ciência, que se sucedem dia após dia, expressam-se, dentre outros, pelos:

- incessantes cortes de recursos para a educação, saúde, ciência e tecnologia;

- perseguição dos profissionais da educação e às instituições de ensino e pesquisa;

- violação da constituição e das normas básicas de convivência, pelo abuso de poder e autoridade;

- cerceamento ideológico e condicionamento dos parcos recursos destinados à pesquisa e manutenção de escolas e universidades à 
adesão e subscrição de projetos de caráter ideológico, de interesses da burguesia conservadora e do governo autoritário e reacionário;

- substituição do conhecimento científico na escola por políticas sociais compensatórias que esvaziam as possibilidades de se ensinar e aprender;

- divulgação e disseminação das fake news;

- incansáveis tentativas de se instituir a "escola sem partido", ou dito melhor, da mordaça, e o homeschooling (ensino domiciliar);

- pressão para transformar a Educação à Distância em rotina escolar, e até mesmo, para acabar com a escola;

- tentativas de substituir a ciência objetiva pela "certeza" da fé, quando não por especulações e superstições;

- combate às medidas de isolamento social defendidas pela Organização Social da Saúde, negando até mesmo os parcos conhecimentos já acumulados sobre o coronavírus e a Covid-19;

- na irresponsável recomendação governamental para tratamento com cloroquina e hidroxicloroquina, que além de não ser recomendada pela Orgnaização Mundial da Saúde (OMS), por pesquisadores e pela grande maioria dos profissionais da saúde, de não trazer benefício algum para a melhoria da Covid-19, pode acarretar uma série de danos colaterais à saúde;

- enfim, nas sucessivas mudanças de ministros da saúde em meio à pandemia, ou em sua ausência, e sua substituição por militares.

Consequentemente, tendo presente que o conhecimento e a ciência estão diretamente ligados à vida, visto que, só existe vida se houver conhecimento e conhecimento se existir vida, os ataques à ciência, aos pesquisadores e aos profissionais da educação e da saúde, no mínimo se constituem num absurdo e, mais do que isso, em um atentado à vida, pois, ameaçam exatamente os responsáveis pela defesa da vida. Assim sendo, os ataques à ciência se revelam como uma elegia à ignorância e à morte. 
A ciência e humanidade estão intimamente ligadas. Consequentemente, só um necrófilo, pode negar à ciência. Além do mais, o desenvolvimento das pesquisas e da ciência é condição indispensável à tomada de decisões, ao planejamento, ao desenvolvimento social, ao aprimoramento da tecnologia, ao aumento da produção, etc. Entretanto, o próprio governo e determinadas frações da classe dominante, do parlamento, da imprensa, da justiça e da sociedade e, em especial, dos fundamentalistas religiosos, em sua pobreza intelectual e sua indigência moral, parecem não medir esforços para bloquear e até mesmo impedir o desenvolvimento do conhecimento e da ciência. O que, na contramão à defesa da vida, significa empreender esforços para se prejudicar a si próprios.

Bastaria, portanto, de um mínimo de inteligência para que estes setores compreendessem que deveriam ser os primeiros a defender 0 incremento dos investimentos na melhoria das condições de trabalho dos profissionais da educação, saúde e na infraestrutura das instituições de ensino e pesquisa. Ao invés disso, são os próprios profissionais que, à despeito de todos os ataques, resistem, trabalham e lutam contra tudo e contra todos em defesa do desenvolvimento científico.

Veja que, neste caso, tratam-se de ataques à ciência entendida no sentido mais elementar, positivista, comtiano, como sinônimo de desenvolvimento cognitivo e técnico, responsável pelo desenvolvimento social, que não só não compromete a forma de organização e funcionamento da atual sociedade, como são adequados a ela. Está longe de ser compreendida conforme entende a PHC, isto é, como condição de vida plena do ser humano, de desenvolvimento de todas as suas dimensões, de formação onilateral. Isto supõe, porém, a superação do atual modo de produção e organização da vida e, por conseguinte, a socialização dos conhecimentos e dos bens materiais mais desenvolvidos, produzidos ao longo da trajetória humana.

Apesar desses ataques se disseminarem também entre os desvalidos da terra, não resta dúvida de que, o combate à ciência faz parte de um 
projeto da classe dominante com o intuito de transformar seus interesses e sua concepção de mundo particular, no interesse geral, tentando dar uma forma de universalidade.

Como afirmam Marx e Engels,

As ideias da classe dominante são, em todas as épocas, as ideias dominantes, ou seja, a classe que é o poder material dominante da sociedade é, ao mesmo tempo, o seu poder espiritual dominante. A classe que tem à sua disposição os meios para a produção material dispõe assim, ao mesmo tempo, dos meios para a produção espiritual, pelo que the estão assim, ao mesmo tempo, submetidas em média as ideias daqueles a quem faltam os meios para a produção espiritual. As ideias dominantes não são mais do que a expressão ideal das relações materiais dominantes, as relações materiais dominantes concebidas como ideias; portanto, das relações que precisamente tornam dominante uma classe, portanto as ideias do seu domínio. Os indivíduos que constituem a classe dominante também têm, entre outras coisas, consciência, e daí que pensem; na medida, portanto, em que dominam como classe e determinam todo o conteúdo de uma época histórica, é evidente que o fazem em toda a sua extensão, e portanto, entre outras coisas, dominam também como pensadores, como produtores de ideias, regulam a produção e a distribuição de ideias do seu tempo; que, portanto, as suas ideias são as ideias dominantes da época. (MARX/ENGELS, 1981, P. 59).

Portanto, o combate a ciência tem como pano de fundo o interesse na manutenção da classe dominante, pois, a alienação também é condição de manutenção e perpetuação do status quo e, consequentemente, de seus privilégios.

Há que se mencionar que o combate à socialização do conhecimento vém de longa data, desde a modernidade a burguesia é avessa e resiste em permitir que os trabalhadores tenham acesso ao sconhecimentos. Senão, vejamos.

Em 1766, o francês La Chalotais (1701-1785), já se posicionava pela rejeição ao acesso aos conhecimentos sistematizados por parte dos Frères Ignorantins (irmãos ignorantes), integrantes do chamado baixo clero. Defendia que, aos pobres e trabalhadores, fossem ensinados apenas os rudimentos do alfabeto.

Afirmava: 
Nunca houve tantos estudantes como hoje. Inclusive gente do povo quer estudar... Ensinam a ler e escrever a gente que só deveria aprender a manejar instrumentos... O bem da sociedade exige que o conhecimento das gentes não vá mais longe do que é necessário para a sua própria ocupação diária. Todo homem que saiba além de sua rotina diária, não será nunca capaz de continuar paciente e atentamente esta rotina... (LA CHALOTAIS apud GUARESCHI, 1986, p. 70-71).

François-Marie Arovet, mais conhecido pelo pseudônimo de Voltaire (1694-1778), seguia na mesma direção. Defendia que não se deveria ensinar as letras aos camponeses e operários para que não viessem a se desviar das tarefas que a natureza e a ordem social lhes haviam determinado.

O padre Réguis, cura de Lisieux, opunha-se terminantemente ao ensino das letras aos trabalhadores, aos escravos, "às gentes do povo". Julgava que era uma verdadeira inutilidade. Afinal, "Não os ensinará a melhor lavrar a terra, não irá Ihes melhorar os costumes, nem Ihes tirar a malícia [...] nem os torna mais dóceis ao seu pastor, nem os torna mais virtuosos e mais cristãos". (MUNDO, 2017).

O Marquês de Condorcet (1743-1794) defendia que a escolarização deveria ser adequada à condição social. Afirmava que "o homem livre que se conduz por si mesmo necessita de mais luzes do que o escravo que abandona sua conduta a um outro". (CONDORCET, 1994, p. 235).

O roterdanês Brernard de Mendeville (1670-1733), por sua vez, afirmava:

A fim de se conseguir, mesmo em circunstâncias difíceis, uma sociedade harmônica e um povo dócil, nada melhor do que a existência de um grande número de analfabetos e de pobres; os conhecimentos alargam e multiplicam os desejos e quanto menos coisas uma pessoa desejar, mais fácil the será obtê-las. (MENDEVILLE citado por GUARESCHI, 1986, p. 71. Nosso itálico).

Nada mais claro, não!? Mas, isso não é tudo. Na Inglaterra, em 1897, a Câmara dos Londres rejeitou um projeto que propunha a escola para todos, sob a justificativa de que,

Em vez de ensinar-Ihes subordinação, (a escola) os tornaria facciosos e rebeldes... Poderiam então ler panfletos sediciosos, livros perigosos... Os tornariam insolentes ante seus superiores; em poucos 
anos, o resultado disso forçaria o governo a utilizar a força contra eles. (Ibidem. Nosso parêntese).

Todavia, a aversão à educação não era/é uma exclusividade da classe dominante europeia, nem dos tempos pretéritos. Entretanto, já que a escola se transformou numa necessidade social, ao invés de negá-la completamente, a burguesia passou a controlá-la e colocá-la a seus serviços.

Ruy Barbosa, por exemplo, que, inclusive, é nome de muitas escolas, defendia que a educação era o principal elemento tanto para a garantia da ordem social, como servia de antídoto às ideias revolucionárias e socialistas.

Mesclando liberalismo e positivismo, Ruy entendia a educação como fator de conformismo e de estabilidade social. "A educação geral do povo", dizia ele, "é o primeiro elemento da ordem". (ORSO, 2003, p. 203).

\footnotetext{
'Se quereis (...) cimentar a ordem necessária das sociedades em bases estáveis, é na escola que deveis lançar. (...) Só o seu espírito disporá da lucidez precisa, para revestir em tempo do tríplice bronze do bom senso contra as loucuras socialistas, contra os ódios inspiradores da subversão revolucionária, e compreender que o nível da demolição, preconizado pelos inventores de organizações sociais em nome da igualdade universal, representa em si, pelo contrário, a mais tenebrosa de todas as opressões, a mais bárbara de todas as desigualdades, a mais delirante de todas as utopias'. (NASCIMENTO, 1997, pp. 119-120).
}

Precisando se desenvolver, foi com este espírito elitista, positivista e liberal, adequado à "ordem e progresso", que, em 1934, a elite paulista, tendo à frente a família Mesquita, donos do "Estadão", na pessoa de Júlio de Mesquita Filho e seu genro Armando de Salles Oliveira, criou a primeira universidade brasileira - Universidade do Estado de São Paulo - USP.

Tratava-se de promover "uma verdadeira revolução espiritual" (ROQUE SPENCER, 1987), com o objetivo de promover a "adaptação definitiva da democracia ao Brasil" (MESQUITA FILHO, 1997, pp. 117, 131. Nosso itálico), isto é, impedir que o país derivasse para o socialismo. Nas palavras do então governador de Minas, Antonio Carlos, tratava-se de "fazer a revolução antes que o povo a fizesse". 
De acordo com o jornal O Estado de São Paulo, era necessário fazer da educação um instrumento para livrar o país "do mal imenso, do mal sem cura, que é a desagregação da República, pela ação dissolvente da politicalha surda e cega ou pela invasão de ideologias subversivas". (CAPELATO, 1980, p. 55).

Assim, ao criar a USP, dentro do espírito elitista, Salles Oliveira afirmava: "Dispomos agora de instrumento através do qual se prepararão as nossas elites dirigentes". Mas não era só isso. Pretendia fazer da universidade "um verdadeiro cérebro, integrando a ciência e a técnica, para forjar uma elite intelectual capaz de orientar todas as classes sociais". "A Universidade de São Paulo", afirmava ele, "é a primeira semente do Brasil novo"5.

Ou seja, mais do que se preocupar com a socialização de conhecimentos, a criação da universidade representava um projeto de educação que objetivava implementar um projeto burguês de sociedade.

Também foi em nome do controle social, que a ditadura militar acabou com o método de alfabetização de jovens e adultos, conhecido como método Paulo Freire, exilou seu idealizador, inseriu as disciplinas de Moral e Cívica, Organização Social e Política Brasileira (OSPB) e Estudos de Problemas Brasileiros (EPB), realizou a Reforma Universitária (Lei $n^{\circ} 5.540$, de 28/1 1/68), instituiu a Lei de Diretrizes e Bases da Educação (Lei nº 5.692 de 11 de agosto de 1971) e implantou o tecnicismo.

Portanto, se a ignorância dos trabalhadores era condição para a manutenção tanto da escravidão quanto da servidão, e a modernidade exigia que tivessem um mínimo de conhecimentos, era necessário controlálos, dosá-los e redirecioná-los para os fins e interesses das elites, mantendo a subserviência dos trabalhadores, de tal modo que não colocassem em risco o status quo.

Recentemente, porém, após a escola básica ter sido praticamente universalizada e o acesso ao ensino superior ter sido ampliado

\footnotetext{
5 Sobre seu túmulo, situado no cemitério ao lado da Rua da Consolação, em São Paulo, foi erguida na vertical, uma vagem para representar a universidade, a semente que havia criado.
} 
significativamente, a burguesia já não se contentava em tentar controlar a educação para impedir que viesse a servir aos interesses dos trabalhadores. Passou ao um ataque cerrado e decisivo, a realizar reformas educacionais, a cortar recursos, atacar os educadores, as instituições e a autonomia universitária, tenta instituir a qualquer custo a Escola sem Partido e o homeschooling, enfim, nega o conhecimento, a ciência, etc., ou seja, agora quer acabar até mesmo com o pouco que resta da escola e do que ainda consegue ensinar.

Afinal, só um povo com um nível cultural extremamente precário, praticamente ignaro, sem senso crítico, individualista, pobre de espírito, admite, apoia e sustenta tantos absurdos, arbitrariedades, agressões contra si mesmo e seus semelhantes.

Os que atacam a ciência, em nome de uma suposta e não muito bem explicada preocupação com a "economia" e a salvação dos "empregos", portanto, para além da demagogia, compõem-se nos principais aliados do vírus e, consequentemente, aumentam sobremaneira seu poder de contágio, letalidade e destruição.

Deste modo, não surpreende que, ao invés de vermos manchetes e mais manchetes comemorando e festejando as vitórias nas lutas em defesa da vida, elas povoam nossos olhos e nossa mente, nos espantam, nos deixam atônitos e assombrados anunciando recordes e mais recordes batidos dia após dia, porém, com o número de infectados e de mortos, que se tornam evidentes, afora as subnotificações e várias tentativas em mudar as formas de registro dos casos, deixando explícito que, para a sociedade burguesa, a economia, o capital, é mais importante que a vida.

Aliás, capitalismo é um termo composto, provém do latim caput, cápitis, que significa "cabeça" e a terminação ismo, que significa que o termo anterior domina. Logo, capitalismo significa um modo de produção em que o capital e o lucro dominam e se encontram em primeiro lugar. Assim, de um lado, fica fácil de entender porque os capitalistas defendem a "economia" acima de tudo e, de outro, para os que defendem a vida, fica fácil de entender que esse modo de produção é anti-humano, que sua 
negação e supreção são imperativos, do mesmo modo que a construção de uma nova sociedade.

\section{O coronavírus, a sociedade de classes, as desigualdades e injustiças sociais}

É desnecessário mencionar, portanto, que vivemos numa sociedade capitalista e de classes, cuja base se encontra na propriedade privada dos meios de produção, centrada na exploração, na dominação e no individualismo. Todavia, não se constitui apenas numa sociedade dividida em classes - capitalistas e trabalhadores - mas sim, numa sociedade extremamente injusta, cuja as diferenças são abissais, em que a liberdade e a igualdade não passam de meras formalidades.

De acordo com dados divulgados em janeiro de 2020, referentes a 2019, pela Oxfam, uma respeitada ONG do Reino Unido, o 1\% mais rico do mundo detém mais que o dobro da riqueza de 6,9 bilhões de pessoas, que corresponde a 92\% da população. Considere que a população do planeta gira em torno de 7,7 bilhões de pessoas. Então, temos 2.153 megaricos que possuem um patrimônio maior do que 4,6 bilhões de pessoas, ou seja, $60 \%$ da população. No caso da desigualdade de gênero, os 22 homens mais ricos do mundo, concentram mais riqueza que todas as mulheres que vivem na África, em torno de 650 milhões.

Mas a desigualdade não é uma exclusividade dos países pobres. Nos Estados Unidos, que é o país mais rico do mundo, por exemplo, em 2017, o $1 \%$ dos mais ricos concentrava $20 \%$ da renda, enquanto $50 \%$ da população mais pobre possuía apenas 12,5\%. Entre 2017 e 2018, quando ocorreu a maior expansão econômica da história, a diferença entre ricos e pobres foi a maior desde 1967, quando se iniciou o acompanhamento. Tomando-se como referência o índice de Gini, que mede a distribuição de riqueza, onde zero representa a igualdade total e 1 a desigualdade total, em 2018, alcançou 0,485, o maior dos últimos 50 anos, quando era de 0,397. Vale mencionar que, nesse período, os países europeus chegaram no máximo a 0,38. (GAZETA DO POVO, 2020). 
No Reino Unido, outro país considerado rico, de primeiro mundo, com uma população de 66,65 milhões (2019), 14 milhões de pessoas viviam na pobreza, o que equivale a $21 \%$ da população.

No Brasil, que no atual momento se parece mais a uma neocolônia, ou então, a um satélite dos Estados Unidos, do que com uma nação autônoma e independente, de acordo com a Oxfam, em 2017, carregava o título nada honroso de vice-campeão mundial em concentração de renda. $1 \%$ mais rico da população ficava com $28,3 \%$ do PIB, atrás apenas do Catar, que concentrava 29\%. Em 2019, de acordo com o IBGE, a Renda de $1 \%$ mais ricos dos brasileiros, chegou a 33,7 vezes a dos 50\% mais pobres, ante 30,5 em 2016. Nesse ano, os $10 \%$ mais ricos tinham um rendimento superior à soma dos $80 \%$ mais pobres.

Em 2019, em plena crise econômica, que foi utilizada pelo governo, pelos ricos e pela mídia golpistas, o que dá no mesmo, como justificativa para realizar reformas e mais reformas e suprimir direitos dos trabalhadores, enquanto o patrimônio dos bilionários brasileiros crescia 13\%, atingindo US\$ 549 bilhões, a fatia da renda dos $50 \%$ mais pobres caia de $2,7 \%$ para $2 \%$, aumento ainda mais o fosso das desigualdades. Nesse mesmo ano, o número de milionários no Brasil cresceu 19,35\%, passou de 217 mil para 259 mil, e o número de bilhonários, que possuem mais de US\$1 bilhão, passou de 42 em 2018 para 58 em 2019.

No país da bandeira verde e amarela, que a partir do golpe de 2015/2016, transformou-se em símbolo de autoritarismo, militarismo, fascismo e repressão, chega-se ao absurdo de que apenas 5 pessoas concentrem uma fortuna de US $\$ 84,9$ bilhões, equivalente à controlada por mais de 100 milhões de pessoas. Registre-se que a população total do Brasil é de 209,5 milhões de habitantes.

Mencionamos aqui apenas o caso dos Estados Unidos, do Reino Unido e do Brasil. Entretanto, essa é a lógica do modo de produção capitalista como um todo, não é muito diferente na maioria dos países. Enquanto nas últimas quatro décadas, isto é, a partir de 1980, o 1\% das pessoas mais ricas capturou um terço da renda mundial, os $50 \%$ mais pobres ficaram com 
apenas $12 \%$. Isso significa que, como vimos acima, nas crises a renda se concentra ainda mais e revela que suas consequências e benefícios não são socializadas de igual forma entre todos. Socializam-se os problemas e misérias e se concentram as riquezas. Os ricos ficam mais ricos, e os pobres, mais pobres.

Aliás, de acordo com a Ofxam, durante a pandemia, o patrimônio dos 42 bilionários brasileiros, aumentou de US $\$ 123,1$ bilhões para US $\$ 157,1$ bilhões, ou seja, aumentou US\$34 bilhões (cerca de R\$176 bilhões) e, na América Latina e Caribe, enquanto os trabalhadores e microempresários tiveram forte diminuição, e até mesmo, ficaram sem renda, a fortuna de 73 bilionários da região registrou uma alta de $17 \%$, aumentou US $\$ 48,2$ bilhões entre março e meados de julho.

Assim, as medidas de isolamento social adotadas para combater o novo coronavírus, em função da ausência de medicamentos e vacinas apropriadas, deve causar um fortíssimo impacto na economia global e provocar a maior recessão da história. De acordo com as projeções o PIB global deve cair mais de 7\%. Segundo o FMl, a economia global deve sofrer uma retração maior do que a provocada pela crise de 1929. Isso provocará enormes consequências nas condições de vida dos trabalhadores.

Tanto a Organização das Nações Unidas (ONU) quanto a Oxfam (2020) estimam que entre 400 e 600 milhões de pessoas, sejam empurrados para a vala da pobreza e se juntem às cerca de 3,6 bilhões que, de acordo com o Banco Mundial (2017) já se encontram vivendo na pobreza no mundo, provocando um retrocesso de mais de 30 anos. De acordo com o PNUD (Programa das Nações Unidas para o Desenvolvimento), O IDH (Índice de Desenvolvimento Humano) global deve recuar pela $1^{a}$ vez desde 1990.

É escusado perguntar se é justa e legítima essa sociedade de classes, marcada por astronômicas diferenças sociais, sobretudo, considerando que quem produz todas as riquezas são os trabalhadores. Claro que não. Trata-se de uma perversa, nefasta e perversa injustiça social.

Nessa sociedade (capitalista), em que a neutralidade é impossível, mesmo que o novo coronavírus desconsidere o centro e a periferia, os 
capitalistas e os proletários, não faça distinção entre pessoas, classes, cor, sexo, nação e continente, a pandemia não deixa de revelar a crueldade desse modo de produção e seu sórdido caráter de classe. Além disso, há que se considerar as diferenças entre os países ricos e os demais.

Contudo, de que valem as riquezas, a concentração de capital e os tesouros acumulados à custa da exploração dos trabalhadores, se um "simples vírus" gelatinoso pode acabar com a vida, até mesmo dos maiores bilionários, e pôr tudo a perder? Não seria melhor se a produção fosse socializada e se garantissem condições dignas de habitação, de proteção, higiene, saúde, educação e vida para todos? Quem sabe se, eventualmente, isso não poderia inclusive, evitar a contaminação dos trabalhadores e até mesmo a morte daqueles que são a razão da penúria dos trabalhadores!?

Já vimos que os capitalistas, apesar de frequentemente se considerarem, não são imortais. Se o vírus é invisível, ninguém está invisível a ele. O perigo aumenta ainda mais quando à arrogância, junta-se a prepotência e a ignorância.

Entretanto, apesar do vírus ser "democrático", não ter preferência, nem fazer escolhas entre ricos e pobres, não atinge, afeta e nem impacta de igual modo as nações, os Estados, as classes sociais, as pessoas e as condições de vida de cada um. Certamente serão os pobres os primeiros a arcar com suas terriveis consequências. Diante do aprofundamento da crise, são as cerca de 3,6 bilhões de pessoas que se encontram na pobreza, sem habitação adequada, sem saneamento básico, sem dinheiro para comprar comida e adquirir álcool em gel e máscaras para se proteger, e as outras cerca de 500 milhões que a ela serão empurradas, que sofrerão seus efeitos mais infaustos, de forma mais imediata, direta, intensa e prolongada. Em pouco mais de três meses do surgimento do novo coronavírus mais de 30 milhões de latino-americanos já haviam sido arremessados para a pobreza.

De acordo com a Organização Internacional do Trabalho (OIT), a estimativa é que, cerca de 1,6 bilhões de trabalhadores informais, ou então, praticamente a metade da força de trabalho do mundo, composta por 3,3 
bilhões de trabalhadores, devam perder de imediato suas condições de sobrevivência. Segundo a Organização, só "no primeiro mês da crise, a renda dos trabalhadores informais caiu $60 \% \mathrm{em}$ todo o mundo. A queda foi de $81 \%$ na África e América, 21,6\% na zona Ásia-Pacífico e 70\% na Europa e Ásia Central". (UOL, economia, 2020).

No caso do Brasil, de acordo com dados do IBGE (2019), tínhamos 65,7 milhões de brasileiros fora da força de trabalho, 27,9 milhões de subutilizados, 13,1 milhões de desempregados $(G 1,2019)$ e $41,3 \%$ dos trabalhadores terceirizados, que, diante da crise, a grande maioria, perde até mesmo as míseras condições que ainda dispunham para sobreviver. Dessa população, cerca de 40 milhões de pessoas nem se quer têm acesso a água e esgoto, ao saneamento básico, e em torno de 15 milhões se encontram abaixo da linha da pobreza. Ou seja, não se trata apenas de uma sociedade dividida em classes, trata-se sim de uma sociedade de classes com enormes, gritantes e espantosas desigualdades.

Em função desse assombroso exército de reserva, a competição e a concorrência também se acirram ainda mais, as condições de vida se degradam e exercem mais pressão sobre os empregos e salários de quem porventura consegue mantê-los.

Some-se a isso, o aumento da violência devido à ausência de emprego e da precarização das condições de vida. E, no caso desses integrantes do exército de reserva serem contagiados, vivendo nas ruas, nas favelas e periferias, sem condições adequadas de saneamento, higiene e alimentação, sem espaço apropriado para se enclausurar e se distanciar de seus familiares, correm o risco de, como num jogo de dominó, transmitir o vírus para todos de forma rápida, direta e sem limites, capaz de eliminar crianças, jovens, idosos, famílias inteiras...

Não nos esqueçamos que a COVID-19 é conhecida como "doença de ricos". Foram eles que, em suas viagens à negócios ou turismo, contagiaram-se, trouxeram para o país e iniciaram a disseminação. Também foram eles que, sob a justificativa de que era necessário "salvar a economia" e os "empregos", exerceram/exercem pressão sobre o(s) governo(s), os 
trabalhadores, os profissionais da saúde e a população em geral para "flexibilizar o comércio", isto é, para fornecer alimento ao vírus.

Cercados em suas mansões e privilégios, enlodados em seu individualismo, narcisismo e egocentrismo, com condições de tratamento e isolamento em caso de necessidade, não se importam se a doença se alastra repentinamente, se os trabalhadores são contagiados, se os postos de saúde e hospitais ficam saturados, se os profissionais da saúde têm ou não equipamentos adequados, se se contaminam, se os serviços funerários dão conta de abrir covas e enterrar milhares e milhares mortos, afinal, para eles, importa salvar a "economia".

\section{A (in)sensibilidade do capital com a vida}

O cinismo dos capitalistas é tal que nem se quer disfarçam para demonstrar sua insensibilidade e desumanidade, para destilar sua demagogia, seu descaso e desprezo em relação à vida.

Em um discurso para investidores, por exemplo, o presidente do Banco Central, Roberto Campos Neto, afirmou que,

Quanto mais rápido vierem novos casos e mortes por covid-19, melhor para a economia. Mais importante é que a indústria continue produzindo e vendendo. Ainda que isso cause o colapso de hospitais e do sistema de saúde pública, forçando médicos e escolher quem atender e quem deixar morrer, é um preço razoável a pagar em nome do lucro. (BRASIL247, 2020).

Nada mais claro do que o próprio presidente do BC falar, sem rodeios, sem meias verdades, o que realmente interessa ao capital.

Apesar da OMS e os governos do mundo inteiro, exceto o Presidente Jair Bolsonaro, que vai na contramão do conhecimento e das experiências acumuladas, defenderem $\mathrm{O}$ isolamento social como forma de evitar $\mathrm{O}$ contágio e a disseminação do coronavírus, o presidente do Banco do Brasil, Rubem Novaes, ao criticar o isolamento social determinado por alguns governadores e prefeitos, foi na mesma direção. Afirmou que a vida não tem 
"valor infinito". "Muita bobagem é feita e dita, inclusive por economistas, por julgarem que a vida tem valor infinito". (AZEVEDO, 2020).

O empresário Junior Durski, dono da rede de hamburguerias Madero e de outros restaurantes, por sua vez, enfatizou:

O Brasil não pode parar dessa maneira. O Brasil não aguenta. Tem que ter trabalho. As pessoas têm que produzir, têm que trabalhar. [...]. Nós não podemos, por conta de 5.000 pessoas ou 7.000 pessoas que vão morrer... eu sei que é muito grave, eu sei que é um problema, mas muito mais grave é o que já acontece no Brasil. (UOL, 2020).

Alexandre Guerra, sócio da rede de restaurantes Giraffas, ao se opor às medidas de combate ao coronavírus, censurou:

Você que é funcionário, que talvez esteja em casa numa boa, numa tranquilidade, curtindo um pouco esse home office, esse descanso forçado, você já se deu conta de que, ao invés de estar com medo de pegar esse vírus, você deveria também estar com medo de perder o emprego? (Idem).

Na mesma esteira, também seguiu empresário e apresentador de TV, Roberto Justus:

Se nós olharmos para o número de casos do mundo, são 300 mil casos de coronavírus no planeta inteiro, são 15 mil mortos. [...] mas 15 mil mortos pra 7 bilhões de habitantes é um número muito pequeno. No Brasil, nós temos [...] 25 mortos, mas 25 mortos para 210 milhões de habitantes, de novo, é um número muito baixo. [...]. Nós estamos exagerando na dose. [...] Nós estamos parando a economia brasileira, [...] o que acontece com isso? Um problema social sem precedentes. Aí, sim, as pessoas vão morrer. Você sabe que muita gente se mata por problemas econômicos. A tristeza de não poder alimentar os seus filhos, perder o seu emprego. Um sorveteiro deu um grande exemplo, ele falou: 'não vou morrer do vírus, vou morrer de fome'. (FOLHA DE SÃO PAULO, 2020).

Outro empresário, colérico e enfurecido com as medidas de isolamento social anunciadas por um determinado governador, foi além, sugeriu outra forma de resolver o problema, à bala. "[...] O negócio é, se a gente não se juntar pra dar um tiro nesse filho da puta desse governador, melhor a gente ficar em casa mesmo cordeirinho [...]" (MADEIRO, 2020).

Essas posições, entretanto, não diferem muito da assumida pelo oncologista e empresário Nelson Teich, que em abril de 2020, assumiu o 
ministério da Saúde, no lugar de Luiz Henrique Mandetta e permaneceu apenas um mês no cargo. Um ano antes, em abril de 2019, afirmou que o dinheiro para a saúde é "baixo" e insinuou que, diante de um dilema, entre salvar a vida de um jovem ou de um idoso "que pode estar no final da vida", a escolha deveria recair sobre aquele. (VALENTE, 2020).

Veja que não estamos nos referindo a opinião e posição de indivíduos quaisquer, estamos vendo a posição da máxima autoridade do país em termos de saúde, de quem seria de se esperar uma posição veemente e um trabalho incansável em defesa da vida e de empresários e autoridades que no mínimo deveriam ter responsabilidade social e respeito os trabalhadores que são a razão de ser de suas riquezas e mordomias.

Não é difícil de imaginar, por suposto, o que se passa pela mente dos idosos que se dedicaram ao trabalho por dezenas de anos e ouviram dizer que era necessário fazer a reforma da previdência para garantir sua a aposentadoria, verem que foram enganados pelos mercadores da saúde, por empresários, pelo governo e pela mídia, que deixam claro seu desdém pela vida e repetem dia sim e outro também que, já que não produzem mais, podem morrer, a previdência agradece.

Isso demonstra não só o descaso com a vida, mas também que para o atual governo e para o capital, ela é totalmente descartável. Aliás, de acordo com relato revelado pela agência Reuters, feito pelo epidemiologista Julio Croda, que foi diretor do Departamento de Imunização e Doenças Transmissíveis (DEIDT), a assessora do governo Bolsonaro e colaboradora do ministro da economia Paulo Guedes e chefe da superintendência de seguros privados, Solange Vieira, que em 2019, defendeu a reforma da previdência, em reunião com técnicos do Ministério da Saúde, em março de 2020, teria dito: "é bom que as mortes se concentrem entre os idosos", que "[A morte de idosos] melhorará nosso desempenho econômico, pois reduzirá nosso déficit previdenciário". (PT, 2020).

Entretanto, "optariam" por salvar a vida dos jovens porque são jovens e tem uma vida pela frente ou porque podem produzir, dos quais, 
pretendem extrair a mais valia? De qualquer modo, em ambos os casos, revelam que no centro das preocupações está o capital.

Além disso, no momento em que o país já tinha um grande número de casos de confirmados, Teich afirmou que a compra de grande quantidade de respiradores, que é um equipamento indispensável para tratar os pacientes que se encontram em estado crítico na Unidade de Terapia Intensiva (UTI), era um "investimento desnecessário".

Por fim, numa espécie de síntese do absurdo, representando o capital, o presidente Jair Bolsonaro, melhor do que ninguém, expressou como o capital considera a vida. Depois de sabotar as orientações da OMS, dos profissionais da saúde e até mesmo dos próprios ministros da saúde, de manter $O$ isolamento social; depois de desconsiderar e ignorar os conhecimentos, a experiência e a ciência acumuladas; depois de, por diversas vezes, desacatar as orientações, estimular e incitar seus eleitores a fazerem o mesmo e descumprir as medidas de isolamento social; quando o Brasil apresentava uma taxa de contaminação de 2,8 - a maior entre 48 países analisados pelo Imperial College de Londres; depois de ter reiterado que era apenas uma "gripezinha", "um resfriadinho", "que não é tudo isso que estão pintando", e que "todo mundo vai morrer um dia", ao ser inquirido sobre as mortes provocadas pela Covid-19, revelando total desrespeito com o sofrimento, a vida e a população de seus país, disparou: "E daí?", "o que eu posso fazer? [...] Não faço milagre!". Parece dizer: O problema não é meu! O que é que eu tenho a ver com isso? Virem-se! Danem-se!!

Para eles, se morrerem 10, 20, 30, 50 ou 100 mil pessoas, ou mais, não importa. Aliás, como vimos anteriormente, no mundo já foram perdidas mais de 600 mil vidas. Se morrer o pai, a mãe, os irmãos, os idosos, também não importa. Importa é "voltar ao trabalho", "salvar a economia" a qualquer custo. Alguns chegam até a afirmar que, se morrer metade da população, o planeta agradece.

Interessante a "nobre sensibilidade" de empresários, do governo e dos capitalistas, em salvar "a economia" e "os empregos", sob a justificativa de 
que os pobres são os que mais sofrem e passam necessidades, ou então, traduzindo, em defender a morte para preservar a vida, não é mesmo?

Antes, porém, nada disso tocava o coração desses altivos patriotas, capitalistas, magnatas. Tanto é que, depois de acumularem muito, forjaram uma crise, aumentaram o desemprego, a violência e a fome para justificar as reformas, retirar direitos dos trabalhadores e concentrar ainda mais capital.

Ou seja, os argumentos são tão frágeis que não resistem ao menor exame. Por vezes, beira a ignorância. Veja que, por exemplo, dizem defender a economia, mas negam a ciência, quando a economia está diretamente dependente da ciência.

De qualquer modo, para serem coerentes, todos os que defendem esse tipo de posição, deveriam começar por dar o exemplo, não é mesmo? Além disso, deveriam se comprometer que, caso se contagiarem, abdicam do uso de respiradores para que sejam usados para salvar a vida de quem a valoriza.

Entretanto, como dissemos, o caráter de classe também está presente no coronavírus. Por conseguinte, caso os hospitais ficarem sobrecarregados, sem equipamentos para atender a todas as demandas e tiverem que "fazer escolha" entre salvar a vida de um trabalhador, um desempregado, um terceirizado, um informal, ou qualquer outro, ou a de um burocrata, um empresário, um banqueiro, por exemplo, o leitor acredita que a opção será feita por quem?

Os dados do DATASUS-SP não deixam dúvidas de que, pior que o coronavírus, para os trabalhadores, é o vírus do capital. Segundo pesquisa do Medida SP, realizada com dados até o dia 18 de maio de 2020, revela que quase $66 \%$ das vítimas viviam em bairros com salários médios abaixo de $R \$ 3$ mil e $21 \%$ em locais com renda inferior a $R \$ 6.500$. Enquanto, nas regiões com renda superior a $R \$ 19$ mil, o número de óbitos atingia pouco mais de $1 \%$ das mortes. (JOANA ASSIS e CAROLINA MORENO, 2020).

Ou seja, ainda que o agente causador seja um minúsculo vírus, "democrático", que não é afeto a fazer distinção de quem quer que seja, o 
pertencimento à classe trabalhadora, o contágio é quase um atestado de morte, o caráter de classe da pandemia se revela nas injustas relações sociais.

\section{A balela do estado mínimo}

A pandemia também se presta para desmistificar, desmascarar os liberais, os capitalistas e o comitê gestor de seus negócios, o estado burguês. Nas últimas décadas, tanto os liberais quanto os capitalistas tripudiaram e demonizaram $\bigcirc$ Estado (social), defenderam açodadamente as privatizações, o estado mínimo, o ultraliberalismo, o laissez faire, a (mal)dita mão invisível, a auto regulação do mercado e, no limite, o darwinismo social, ou então, a defesa do individualismo e a lei do mais forte.

Assim, cantarolavam e repetiam a ladainha de que cada um deveria se virar por conta própria, sem depender do Estado. "Ensinem a pescar, não deem o peixe", repetiam. Assim, intensificaram os ataques aos trabalhadores, destroçaram os sindicatos, cortaram recursos e sucatearam as instituições de ensino, de pesquisa e extensão e desmontaram o Sistema Único de Saúde (SUS), em benefício dos empresários da educação e saúde, cujo único interesse é o lucro.

Com isso, as universidades públicas, responsáveis por mais de $90 \%$ das pesquisas, foram privadas de fazê-las, ou pelo menos, tiveram sua capacidade profundamente abalada, e as instituições de saúde destinadas ao atendimento da população carente foram deixadas à míngua. No entanto, diante das ameaças à vida, contraditoriamente, a pandemia se encarregou de demonstrar tanto a importância e necessidade das universidades públicas, como o fortalecimento dos Sistema Público de Saúde, escancarando o fracasso das políticas privatistas e do malfadado estado mínimo.

Aliás, que estado mínimo, mínimo em quê e para quem? Apropriado pela decadente classe dominante, por uma pequena fração da burguesia, o estado foi transformado numa espécie de monstro pavoroso, um leviatã, 
um ser soberano, absoluto, utilizado para aniquilar, controlar, reprimir, coagir, destrir "direitos" e ampliar a transferência de riquezas dos trabalhadores para o capital.

Contudo, diante da crise desencadeada pela Covid-19, ao invés dos capitalistas serem consequentes com suas arengas e arcarem com suas responsabilidades, sem receio, nem pudor, mais uma vez, jogaram suas gabolices ideológicas na lata do lixo e, de forma cínica e sem escrúpulos, utilizaram-se do Estado e exigiram o despejo de montanhas de reais/dólares na tentativa de salvar a (sua) "economia", seus interesses.

Sob a justificativa de que o Estado estava em crise, que não havia recursos para pagar os aposentados, a classe dominante promoveu uma intensa campanha midiática, fez uma verdadeira e massiva "lavagem cerebral", com o intuito de convencer os trabalhadores de que era necessário "modernizar" e "enxugar o Estado". Com isso, realizaram um conjunto de reformas, desde a Reforma do Ensino Médio, a aprovação da Base Nacional Comum Curricular (BNCC), o congelamento dos investimentos por 20 anos em educação e saúde, a Reforma Trabalhista, a Terceirização, realizaram a Reforma da Previdência, dentre outras. Todas suprimiram os direitos dos trabalhadores, (ORSO, 2020b), que, no intuito de camuflar e escamotear a relação de subordinação ao capital, denominam de colaboradores.

Entretanto, eis que, para a surpresa de todos, já que, como afirma Karl Marx, (2020), "os homens fazem sua própria história, mas não a fazem sob circunstâncias de sua escolha e sim sob aquelas com que se defrontam diretamente [...]", sobrevém a pandemia da Covid-19. Aí, não mais que de repente, tanto no Brasil quanto no mundo, parece que começou a "brotar dinheiro", aparecer montanhas e mais montanhas de dinheiro, despejados para salvar bancos, empresas e até mesmo algumas migalhas para os pobres mortais, os mais pobres dos pobres.

O Brasil, a União Europeia e Estados Unidos, por exemplo, liberaram os maiores pacotes econômicos de sua história sob a justificativa de enfrentar os impactos do coronavírus na economia. Em nosso país, o ministro da 
economia, o ultraliberal Paulo Guedes, liberou $R \$ 1,2$ trilhões para os bancos (que, não custa lembrar, estão na lista dos maiores devedores da previdência), $R \$ 750$ bilhões para socorrer empresários e $R \$ 98,2$ bilhões para auxílio emergencial. A União Europeia liberou $€ 750$ bilhões, cerca de R\$ 4,427. No império do norte, Trump anunciou a liberação de US\$2,484 trilhões, em torno de $R \$ 12,68$.

Veja que, após terem "golpeado e assaltado o Estado", fizeram reformas e despejaram a conta sobre os trabalhadores. Aliás, assim como nenhuma das reformas acarretou qualquer prejuízo ao capital, nenhuma delas garantiu qualquer direito aos trabalhadores, exceto para os militares que, legislando em causa própria, fizeram uma reforma previdenciária que se transformou num plano de carreira, com muitos ganhos.

Aliás, mais uma vez a realidade se encarrega de desmistificar e desmascarar os discursos demagógicos e hipócritas. Veja que, no momento de repartir as "ajudas" liberadas pelo estado diante da crise, os "colaboradores" já não mais contam. A astronômica diferença entre as "generosas ajudas" liberadas para bancos e empresários e as migalhas dadas para os trabalhadores, explicitam o engodo camuflado sob o disfarce de "colaboradores".

Além disso, os capitalistas se aproveitaram do momento em que a absoluta maioria do parlamento é pró-capital para transformar o Estado no garantidor exclusivo de seus interesses. Desse modo, promovem reformas, dão isenções fiscais e abonam juros de dívidas e ampliam ainda mais concentração do capital. No entanto, com a chegada do novo coronavírus, sem ficar ruborizados, não hesitar, jogaram o discurso falacioso de defesa da mão invisivel às calendas e, à "plena luz do dia", transformaram-se nos maiores defensores do intervencionismo estatal, em benefício próprio.

Incrível, não!? Afinal, o Estado não estava em crise? Não foi sob esse discurso que fizeram a reforma do Estado? Não foi sob essa alegação que fizeram a reforma e alteraram mais de 100 artigos da CLT? Agora não estão mais preocupados em enxugar o Estado e reduzi-lo ao mínimo? 
Até mesmo nesse intervencionismo desavergonhado fica escancarado, explícito e evidente o caráter de classe. Foram destinados 20 vezes mais recursos para meia dúzia de endinheirados (bancos e empresários) do que para auxílio emergencial de $R \$ 600,00$, liberado para cerca de 60 milhões de pessoas em estado de vulnerabilidade social. Além disso, não custa lembrar que, em 2019, o lucro dos quatro maiores bancos do país (Itaú Unibanco, Banco do Brasil (BB), Bradesco e Santander), bateu o recorde histórico, cresceu $18,4 \%$, diante de uma inflação de $4,31 \%$, e atingiu $\mathrm{R} \$ 86,6$ bilhões.

Diante disso perguntamos: Qual trabalhador teve $18,4 \%$ de aumento no salário durante o ano e ainda recebeu uma generosa ajuda do governo? Claro que nenhum trabalhador não só não recebeu nem mesmo as migalhas do governo, como a maioria, nem se quer teve reposição das perdas inflacionárias e vem acumulando anos e anos sem data-base, além de amargar um congelamento por 20 anos.

O cinismo e o descaramento é tal que, depois de terem obtido um lucro extraordinário, depois de empresários e banqueiros terem recebido praticamente dois trilhões de reais do governo para salvar a "economia", alguns deles se apresentam como "generosos" e "benfeitores", anunciando uma "contribuição" para combater os efeitos da crise provocada pela Covid-19, como no caso do Itaú Unibanco que anunciou a doação de R\$ 1,25 bilhões, Suzano Celulose R\$ 60 milhões, BRF, BTG Pactual, iFood e Votorantin $R \$ 50$ milhões cada, Banco do Brasil $R \$ 40$ milhões, Cacau Show R\$ 32 milhões, Banco Safra, BV e Stone 30 milhões cada, dentre outros.

É muita desfaçatez, não? Não estavam em crise? Não defendiam a necessidade de fazer reformas para superar a "crise"? Então, como é que apareceu, de onde saiu tanto dinheiro?

Não custa lembrar, porém, que, aquilo que alardeiam como generosidades, não tem outra origem senão a exploração do suor dos trabalhadores, que foi expropriado e acumulado indevidamente. Primeiro exploram os trabalhadores. Depois utilizam parte das riquezas suprimidas e as apresentam como se fossem generosos. Como dizem, "é fácil fazer 
generosidade com chapéu alheio". Mesmo assim, essas "ajudas" não passam de migalhas quando comparadas com os lucros ou aos recheados pacotes despejados pelo governo aos bancos e empresários, inclusive, sem exigir qualquer contrapartida.

Todavia, já que os nobres banqueiros e empresários estão enternecidos com o sofrimento e as carências alheias, como as tais bondades são resultados da exploração alheia, porque não aproveitam para socializar todas as riquezas, devolver aos trabalhadores aquilo que Ihes foi expropriado, que Ihes faz falta, que os impede de satisfazer suas condições básicas de sobrevivência e, portanto, fazer com que necessitem de "ajuda" para se manter vivos? Se a sociedade fosse igualitária, não haveria carência de um lado, nem "pessoas do bem" de outro, fazendo caridade para tentar obter o passaporte para o paraíso. Afinal, como dissemos: de que valem as riquezas acumuladas por alguns, se elas fazem muita falta a outros, diante de um vírus que não faz distinção de ninguém?

Numa sociedade minimamente civilizada e humana, entretanto, dada a situação de miséria e degradação social, aprofundada pela Covid-19, seria de se esperar que, depois do período de quarentena e do rebaixamento das condições de vida dos trabalhadores, os empresários e o governo (ultraliberais) não exigissem mais sacrifício dos trabalhadores. Entretanto, como sabemos, não são dados a ter dó, piedade ou compaixão, nem comiseração, tem sim interesses. Todos os indicativos dão mostras de que não terão clemência, vão continuar com as famigeradas reformas, ampliar os ataques e avançar ainda mais sobre os direitos e as condições de vida dos trabalhadores.

Aliás, em meio à crise instalada/aprofundada com a pandemia do novo coronavírus, o ministro da economia, Paulo Guedes, atendendo ao gosto, sabor e apetite dos empresários, investidores/especuladores e banqueiros, chamou os funcionários públicos de "parasitas" e mandou recado aos trabalhadores: "Estamos indo em direção a uma economia voltada para o mercado, [...] Qualquer um que não possa ver isso está interpretando mal o Brasil", "As reformas vão continuar", "Vamos continuar 
com a reforma do estado brasileiro". E encaminhou um ofício ao congresso nacional pedindo para "acelerar a pauta das reformas". Sabemos todos, porém, que, para os trabalhadores, "reformas" significam mais ataques, mais precarização, menos direitos. Numa figura, é como se o Titanic estivesse enchendo de água por todos os lados, e Guedes acreditasse que a saída é fazer mais buracos na embarcação.

$\mathrm{Na}$ verdade, o que as aves de rapina que pousaram suas garras sobre - Estado pretendem, para além dos seus discursos demagógicos, não é acabar com o Estado e com o público. Como diria Francisco de Oliveira, pretendem reduzi-los à uma "caricatura de interesses privados", expressão de "uma regressão conceitual, máscara da regressão/repressão brutalizadora" (2020, p. 26).

Desse modo, como uma espécie de big father, rude, grosseiro, agressivo, autoritário e repressor, o governo e os capitalistas não conhecem outra linguagem que não seja: "É preciso continuar com as reformas", "É preciso reduzir o estado!", "Privatiza tudo!", "Ataca o funcionalismo!", "Ataca os trabalhadores!". Contudo, de forma irônica, debochada e sarcástica, dizem que é necessário fazer isso para "aumentar os investimentos", "gerar empregos", "salvar e desenvolver o país" ..., noutras palavras, dizem que é pelo bem dos próprios trabalhadores. Ou seja, botam a "granada" no bolso do funcionalismo e dizem que é para salvar a sua viva.

Aliás, nem se quer esperam pelo final da crise. Enquanto o governo destina cerca de $R \$ 2$ trilhões para bancos e grandes empresários e se aproveita da própria crise e do momento, quando os trabalhadores se encontram mais frágeis após à destruição de seus direitos e entidades representativas, e estão em quarentena, manietados, imobilizados, sem poder reagir, apressa-se em aprovar medidas em favor do capital, como por exemplo, reduzir jornada de trabalho e salários em até $70 \%$, extinguir carreiras (Paraná) e estabelecer um novo congelamento de salários dentro 
do congelamento' por 18 meses, como condição para "ajudar" os estados e municípios.

Ressalte-se que, enquanto essa tal "ajuda" chega a cerca de $R \$ 50$ bilhões, o congelamento dos salários do funcionalismo, garantirá $R \$ 125$ bilhões ao governo. Isso significa não só, como sempre ocorre, que os trabalhadores irão pagar a conta dessa "ajuda", como irão financiar a crise, gerar caixa para o governo, transferir renda e engordar ainda mais o capital. E de quebra, justificar que o Estado está em crise e que é preciso aprofundar as reformas, retirar mais direitos e ampliar a precarização das condições de trabalho e vida dos trabalhadores.

Nesse sentido, é exemplar a fala do ministro da economia, Paulo Guedes, feita durante a reunião ministerial, no dia 22 de abril de 2020, com o presidente da república e os demais ministros, revelada em áudio divulgado por autorização do STF. Veja que usa a palavra granada, como mencionamos na nota 2, para se referir à forma de ataque que promove contra os servidores públicos.

"É nessa confusão toda, todos estão achando que estamos distraídos, abraçaram a gente, enrolaram a gente, mas já botamos a granada no bolso do inimigo, dois anos sem aumento de salário" (SIMONARD, 2020). E completou o "excelentíssimo" senhor ministro: "Nós vamos ganhar dinheiro usando recursos públicos para salvar grandes companhias. Agora, nós vamos perder dinheiro, salvando as pequenininhas".

Ou seja, não é por acaso que o governo e o ministro Guedes resistiam até mesmo em dar $R \$ 150,00$ de auxílio emergencial aos mais pobres durante a pandemia, que depois, por conta da pressão da oposição no Congresso, com muito mau gosto, chegou a $R \$ 600,00$ e resiste em conceder empréstimos aos pequenos empresários. Veja que depois de

\footnotetext{
6 Diz respeito a um novo congelamento de salários proposto aos servidores, pelo ministro da economia Paulo Guedes, para pagar a conta da crise gerada pelo novo coronavírus. Não custa lembrar que, em 2016, o governo golpista de Michel Temer já havia aprovado o congelamento de gastos com educação e saúde por 20 anos. Em 2020, em meio a pandemia da COVID-19, após dar praticamente dois trilhões de reais aos bancos e empresários, exige mais sacrifício dos trabalhadores com novo congelamento de salários por 18 meses.
} 
aproximadamente 5 meses do início da pandemia, dos $R \$ 40$ bilhões que deveriam ser destinados aos micro e pequenos empresários para ajudá-los a enfrentar a crise, apenas $3,6 \%$ do total foi emprestado. O restante permanece nas mãos dos banqueiros rendendo juros pagos pelo governo. Não resta dúvida que se trata de um governo voltado exclusivamente para os ricos, banqueiros, empresários, latifundiários, pastores, etc.

É claro que, se a fala de Guedes em defesa das grandes companhias, em favor da "redução do estado" e das privatizações, desagrada a grande maioria da população, não se pode dizer o mesmo dos banqueiros. Aliás, não é para menos que "O presidente da Associação Brasileira de Bancos Comercial (ABBC), Ricardo Gelbaum, afirma que o mercado financeiro viu com bons olhos a participação do ministro da Economia, Paulo Guedes, na reunião ministerial". (MILITÃO e ARAÚJO, 2020).

Essa fala, agrava-se ainda mais, quando se percebe que não é uma fala isolada de um ministro. Ela se soma a outras proferidas por Bolsonaro e seus ministros, escancarando, assim, os embustes usados para justificar os ataques aos trabalhadores e, em especial, ao funcionalismo público.

Assim, utilizando-se de falácias e da imprensa, sustentada e bancada por grandes empresários, interessados nas reformas, também foram construídas as justificativas para "ir passando a boiada" e fazer todas as reformas, em especial, a da previdência.

Na mesma reunião ministerial já mencionada, que está longe de servir de exemplo de civilidade, moralidade, zelo pela coisa pública, conduzida pelo "ilustríssimo" presidente da república e seus "eminentes" ministros, sem qualquer preocupação com o sofrimento provocado pelo pior dos males que afligem a população do país, a Covid-19, que já ceifou dezenas e mais dezenas de vidas, Ricardo Salles, ministro do meio ambiente, expressou com limpidez a forma desse ação do governo.

[...] precisa ter um esforço nosso aqui enquanto estamos nesse momento de tranquilidade no aspecto de cobertura de imprensa, porque só fala de covid (sic) e ir passando a boiada e mudando todo o regramento e simplificando normas. De Iphan, de Ministério da Agricultura, de Ministério de Meio Ambiente, de ministério disso, de 
ministério daquilo. Agora é hora de unir esforços pra dar de baciada

a simplificação regulam [...]. (URIBE, 2020).

Ou seja, de acordo com os ministros, isto é, falando de forma redundante, de acordo com o próprio governo, o governo deveria se aproveitar do sofrimento da população para agravá-lo ainda mais, seja com a perda de vidas, familiares e amigos, com a perda de empregos, com o fechamento de empresas, e fazer reformas para agradar uns poucos bancos, grandes empresas e latifundiários. A tragédia só não é maior do que a representada pelo nível da equipe de governo.

Registre-se que tudo isso está ocorrendo no momento em que a tecnologia se encontra extremamente desenvolvida e o capital mais concentrado do que nunca, superacumulado, e, a despeito de toda a demagogia, ao invés das reformas serem realizadas em benefício do bem estar do conjunto dos trabalhadores, produtores da riquezas, visam única e exclusivamente ampliar ainda mais a acumulação do capital.

Se no atual momento o coronavírus demonstrou que, para ele, todos são iguais, a sociedade de classe se encarrega de confirmar que todos são diferentes. O capital sempre considerou os trabalhadores abomináveis, uma espécie de leprosos, que precisa manter distância. Utiliza-se deles apenas quando e como the convém e depois os descarta. Aliás, o último general presidente do Brasil, João Batista Figueiredo, dizia que preferira "cheiro de cavalo a cheiro de gente".

Portanto, se antes e durante a pandemia, os trabalhadores já eram/são perseguidos e transformados nos responsáveis por pagar a conta da crise, passada a pandemia, a ojeriza ao trabalhador, certamente aumentará. Sem um inimigo "comum", como no caso do coronavírus, o trabalhador passará a ser visto como uma espécie de ser estranho, a perseguido e combatido. A conta certamente continuará a ser repassada e jogada para os trabalhadores.

O interessante é que, se durante a crise do coronavírus, o governo, o ministro da economia e os empresários falam que é momento de se unir, juntar forças, dar a contribuição para superar esse momento difícil, os 
trabalhadores não devem se iludir e se enganar achando que no momento ulterior à crise, serão mais piedosos, condescendentes, complacentes e generosos com eles.

Além do mais, as tecnologias da informação (TICs) não serão utilizadas apenas para educação de tipo EaD, o que, por si só, já seria um grande problema. As medidas de controle social, de geolocalização, de home office (trabalho em casa), viabilizadas, toleradas e aceitas em tempos de pandemia e isolamento social, que se somam à toda a parafernália de câmaras, chips e demais equipamentos tecnológicos de rastreamento e monitoração já existentes, no they after não só não serão extintas, como serão utilizadas para aprofundar ainda mais o controle social, a repressão, a extração da mais valia e a divisão em classes, em desfavor dos trabalhadores.

\section{A economia ou a vida, um falso dilema}

É um absurdo discutir se a economia ou a vida é mais importante, como faz o governo e os empresários. Beira ao irracionalismo. Aliás, não se sabe se existe algo de racional no governo Bolsonaro, pelo menos, no que tange aos interesses da maioria da população. Na verdade, para o governo e empresários não há dúvida sobre o dilema, nem está em discussão, defendem pura e simplesmente a economia, o capital e o lucro acima de tudo e de todos. Consequentemente, combatem a ciência, o "isolamento social", contrariam as orientações da OMS, não se importam se existem hospitais e equipamentos adequados às eventuais demandas da maioria da população, nem se um grande número de idosos, de pessoas com comorbidades, de trabalhadores e profissionais da saúde perecam.

"Acreditam" que são inatingíveis, por conseguinte, dizem: "A economia não pode parar!". "Como as pessoas vão sobreviver se a economia parar?" Assim, constituem-se numa ameaça tanto à economia, quanto à vida e à sociedade. Sim falamos de ameaça até mesmo à economia, pois, expondo os trabalhadores a riscos desnecessários, podem 
contaminá-los e levá-los à morte, comprometendo não só a vida como a própria economia, que tanto dizem defender. Afinal, o que seria dos empresários sem os trabalhadores? Ou seja, como dissemos, não se sabe quem é mais nocivo, se o coronavirus ou o capital.

Aliás, seja por conta dos diferentes tipos de vírus e bactérias, das epidemias e pandemias, seja por conta dos ataques e da voracidade do capital, a vida dos trabalhadores tem sido constantemente posta à prova. "Está difícil de respirar" e sobreviver a tantos e tão cerrados ataques!

Entretanto, já que, num gesto nobre, defendem a economia, afinal, dizem que estão preocupados em salvar $a / s$ vida/s, perguntamos: Será possível salvá-la sem colocar em risco a/s vida/s? Na sociedade capitalista, como vimos, não é possível, pois, a tal "economia" se constitui num privilégio para poucos. Para mais de $90 \%$ da população, há muito tempo ela já foi suprimida. Logo, não é verdade, senão em raríssimos casos, que os capitalistas estão preocupados com a economia para salvar as vidas.

Ademais, se assim fosse, antes da pandemia não haveria ninguém passando fome ou morrendo de inanição, não é mesmo? Então, vejamos como e em que condições de fato é possivel colocar a economia em primeiro lugar e, consequentemente, defender à vida.

Como aludimos anteriormente, a educação e, em especial, a educação na perspectiva da Pedagogia Histórico-Crítica não pode desconsiderar a relação com a sociedade. Para a PHC, que adota como método o materialismo histórico-dialético, é indispensável considerar a realidade social, pois, a educação não só ocorre numa sociedade concreta, como as condições sociais interferem nela. Além disso, dada a configuração social existente, não se coloca outra alternativa aos educadores senão fazer da educação um instrumento de compreensão e transformação de si e do mundo (ORSO, 2016, p. 110), pois, como mencionamos, se fizermos mais do mesmo, os problemas recrudescerão. É necessário transformar.

É inadmissível se trabalhar para reproduzir e perpetuar um modo de organização societário extremamente injusto, simultaneamente, concentrador de capital e concentrador de misérias, em que $1 \%$ da 
população detém riqueza equivalente à controlada por mais da metade da humanidade, ou que, apenas 5 pessoas tenham mais riquezas do que $50 \%$ dos brasileiros.

Diferente disso, a PHC defende a

[...] igualdade essencial entre os homens. Entende porém, a igualdade em termos reais e não apenas formais. Busca, pois, converter-se, articulando-se com as forças emergentes da sociedade, em instrumento a serviço da instauração de uma sociedade igualitária. (SAVIANI, 1999, p. 73).

Ou seja, os defensores dessa teoria pedagógica defendem uma transformação substancial da sociedade. Afinal, como vimos, seja em função da divisão da sociedade em classes, da voracidade do capital, das absurdas diferenças sociais, das doenças e pandemias ou das violências (de todas as formas), para a absoluta maioria da população, essa sociedade se revela um lugar inóspito, malcheiroso, fétido, irrespirável e anti-humano. Além disso, como nos lembra Marx, o trabalhador só vive se tiver trabalho e só têm trabalho se produz lucro, e se tem lucro é expropriado pelos proprietários dos meios de produção.

A crise econômica, política e social desencadeada pela pandemia da Covid-19, aprofunda-se ainda mais com o negacionismo científico que cavalga à galope, com os ataques à ciência, aos docentes, aos conteúdos escolares e às universidades, enfim, à educação como um todo, e, com a pandemia de desinformação, ou então, com a infodemia, um neologismo que diz respeito às notícias falsas ou pouco confiáveis, espalhadas em torno da pandemia gerada pelo coronavírus, e das fake news que se disseminam pelo Brasil e pelo mundo, espalhando desinformação, fomentando preconceitos e violência.

No caso da educação, os problemas enfrentados pela classe trabalhadora decorrentes das gigantescas desigualdades sociais, não só não se congelam, como, em função do isolamento social e da redução das atividades econômicas, agravam-se sobremaneira com o extraordinário 
aumento do número de inadimplência de alunos das escolas privadas ${ }^{7}$ e com a adoção da Educação à Distância. As desigualdades sócio econômicas também se revelam nas incomensuráveis desigualdades nas condições de vida e de acesso às tecnologias e conhecimentos. De acordo com o Instituto Brasileiro de Geografia e Estatística (IBGE), 45,9 milhões de brasileiros (2018), o que equivale a quase $1 / 4$ da população, nem se quer tem acesso à internet. Assim, ao invés das tecnologias encurtarem o isolamento entre as classes, alargam ainda mais as distâncias sociais.

Consequentemente, como a educação se constitui na forma como a sociedade prepara e educa os indivíduos para viverem nela mesma, (ORSO, 2020a, p. 3841), cabe aos profissionais da educação, integrantes da classe trabalhadora, "lerem o mundo" e, por meio do trabalho que executam, trabalhar para produzir um mundo habitável, respirável e humano, em que o homem possa se desenvolver plenamente, em todas as suas dimensões e potencialidades. Ou então, como nos diz Saviani, para "[...] produzir, direta e intencionalmente, em cada indivíduo singular, a humanidade que é produzida histórica e coletivamente pelo conjunto dos homens". (1991, p. 2030).

Entretanto, nos encontramos numa encruzilhada. De um lado está o caminho em direção à morte, e de outro, o que pode conduzir a uma nova humanidade. Depende de nós... Contudo, a realidade e os fatos que vimos e a história que percorremos indicam que não podemos continuar a fazendo mais do mesmo, necessitamos de uma teoria pedagógica que assuma explicitamente o compromisso com a transformação social, como o faz a Pedagogia Histórico-Crítica, que se constitui numa teoria pedagógica contra hegemônica, que valoriza os profissionais da educação, defende a escola, a existência da realidade objetiva e do saber objetivo, a relevância da ciência e do planejamento escolar, com a finalidade de propiciar a socialização dos conhecimentos mais desenvolvidos produzidos histórica e coletivamente

\footnotetext{
7 Segundo a Secretaria de Modalidades Especializadas de Educação (Semesp), "em um cenário "realista", o índice (de inadimplência) deverá ficar em 33,1\% em 2020". (AGÊNCIA BRASIL, 2020). Lembremos que a inadimplência, em geral, vem junto com a desistência dos alunos da escola.
} 
pelos homens e que atua nas contradições existentes objetivando a construção de uma sociedade em que todos possam usufruir tanto dos bens espirituais (conhecimento, ciência, cultura), quanto dos bens materiais, e sejam felizes.

Dada essa exigência, não basta se preocupar com a didática, com a metodologia, nem com a psicologia. Não basta fazer bem feito o trabalho no interior da sala de aula. É necessário se preocupar com a totalidade que envolve o processo educativo, tanto no interior da escola, como para além dela, e fazer com que, por meio do trabalho pedagógico, os educandos superem suas compreensões espontâneas, aparentes, cotidianas, confusas, caóticas e, por vezes, alienadas, próprias dessa "escola da vida", do "aprender fazendo", do "aprender com a vida", adquiram a capacidade de compreender e interpretar o mundo na sua radicalidade, de forma histórica, crítica, sistematizada, objetiva e científica.

Todavia, para realizar seus fins, enquanto uma pedagogia revolucionária, que pretende suprimir as classes e toda porcaria delas decorrentes, transformar a sociedade e possibilitar $O$ desenvolvimento humano pleno, a PHC pressupõe uma didática, uma metodologia, planejamento, organização do trabalho pedagógico, sequenciação e articulação dos conhecimentos e coerência entre seus pressupostos, sua prática e seus fins.

Para tal, não é suficiente constatar, de modo abstrato e a-histórico, a existência das classes ou considerar que se trata de uma sociedade capitalista. Diferente disso, uma vez que se trata de agir e transformar a realidade objetiva, é necessário acompanhar $\bigcirc$ movimento das contradições, considerar e compreender como efetivamente se configura a materialidade em cada momento. Daí a exigência da perspectiva materialista histórica (ORSO, 2018, p. 81).

Porém, se o ato educativo ocorre localmente, não podemos esquecer que seus determinantes não se limitam ao interior da escola; eles são globais. Em função disso, como dissemos, por um lado, não podemos resumir nossa preocupação à simples didática, à metodologia e à psicologia escolar, 
ainda que sejam indispensáveis à consecução dos fins educacionais. Por outro, a importância de os educadores se identificarem enquanto classe, considerarem a totalidade das relações e, consequentemente, arregimentarem o internacionalismo proletário para enfrentar os desafios que afligem os trabalhadores, tanto em escala local, quanto global.

Para os trabalhadores, sejam eles da educação ou pertencentes a qualquer outra categoria, portanto, não se coloca outra alternativa senão a luta com todas as forças pela superação de sua condição. Pois, como nos diz Marx, "A emancipação dos trabalhadores será obra dos próprios trabalhadores", ou não será. Aliás, ainda que seja ilusão, é bom lembrar aos capitalistas para também lutar pela superação de sua própria condição, pois, por trás da aparência de superpoderes, esconde-se uma fragilidade extrema. Afinal, sem os trabalhadores, o capital não é nada. Por isso, em geral, tentam camuflar essa fragilidade com grosserias, arrogâncias e buscam se impor pela força, da mesma forma que o dono do touro se impõe a ele pelo chicote.

A fragilidade do coronavírus e também do capital, advém do simples fato de que nenhum deles tem vida própria, autônoma e independente. Ambos são "parasitas", sobrevivem apenas à custa de outro.

Apesar de ser muitíssimo poderoso e se disseminar com uma velocidade meteórica, com altíssimo poder de contágio e um extraordinário poder de destruição, capaz de impor confinamento social forçado a mais da metade da população do globo terrestre e levar à morte centenas de milhares de pessoas, ao aniquilar seu hospedeiro, acaba consigo mesmo.

A pandemia e $O$ isolamento social também revelam a fragilidade do capital, abalaram sua estrutura, trouxeram à tona e expuseram seu segredo mais protegido - a riqueza é produzida pelos trabalhadores. Diante disso, reagiram e ficaram nervosos. Na tentativa de camuflar e esconder essa verdade sagrada e incontestável, realizaram as bizarras "carreatas da morte", proferiram discursos inflamados em defesa da "economia" e dos "empregos", foram para a rua sem máscaras, contagiaram-se e 
contagiaram, pressionaram governos a reabrir o comércio - a "economia não pode parar", falavam.

Além disso, desconsiderando as orientações da organização mundial da saúde e dos pesquisadores, promovem atos antidemocráticos, defendem o autoritarismo, imploram pelo retorno dos militares e, até mesmo, defendem a morte como preço a pagar em nome do lucro. Ou seja, não querem apenas explorar os trabalhadores, querem que eles se submetam incondicionalmente, entreguem seu próprio sangue e sua vida. Ao invés da bioconomia defendem a necroeconomia8.

Beira a insanidade, não? Além disso, dá para considerar como séria a preocupação com a "economia" negando a ciência? Até mesmo o império do norte, o maior do mundo, que possui o exército mais poderoso do planeta e conta com mais de mil bases militares ao redor do globo, encontra-se armado até os dentes, ameaça, amedronta, arquiteta golpes, derruba governos e subjuga povos mundo afora, expôs sua fragilidade, debilidade e vulnerabilidade diante de um vírus gelatinoso.

Diante de um ser minúsculo, o temível império se apequenou, pareceu-se a um rastejante. Todo o seu poderio se revelou inútil, impotente e incapaz de enfrentar até mesmo um ser microscópico, um pequenino vírus. Basta ver que os United States of America apresentou o maior número de casos de coronavírus e o maior número de mortos.

Portanto, se falávamos que não dá para saber quem é mais perigoso, se o capital ou o coronavírus, na verdade, percebe-se que o mais nocivo é o capital, pois, ao se colocar em primeiro lugar, acima de tudo, ao "forçar" as pessoas retornarem a seus postos de trabalho, com a movimentação das indivíduos, fornece alimento ao coronavírus, aumenta os contágios, sobrecarrega os postos de saúde e hospitais, expõe os profissionais de saúde a riscos excessivos, aumenta os gastos públicos com o tratamento dos infectados e o combate à Covid-19 e, por conseguinte, também a letalidade.

8 Termos derivados gregos que significa economia da vida e economia da morte. 
De qualquer modo, tanto para o mais frágil dos homens, como para o mais poderoso império, o novo coronavírus se encarregou de revelar a tremenda fragilidade humana. Isso pressupunha que, caso queira sobreviver, um ser minimamente inteligente percebe a necessidade de mudar sua forma de se organizar e viver. Caso contrário, se o individualismo imperar, se a ignorância e a soberba prevalecerem, a natureza que, como dissemos, não é dada a fazer distinção de quem quer que seja, não perdoará ninguém.

Como se pode verificar, seja por conta do capital ou da pandemia, não está fácil de sobreviver na sociedade de classes. Por diferentes razões, a prática social atual, revela-se extremamente perigosa, em especial para os trabalhadores. Por isso, cabe à educação na perspectiva da Pedagogia Histórico-Crítica, partindo da prática social atual, considerando a totalidade das relações e condições existentes, identificar os problemas postos pela realidade, mediar a superação dos mesmos (SAVIANI,1983, p.73) e garantir a existência.

Sim, porém, para isso, não há dúvida de que é necessário suplantar o atual modo de produção, que supõe a negação da propriedade privada, das classes, das lutas de classes e colocar a economia a serviço da vida, transformar a necroeconomia em bioeconomia. Afinal, como nos diz Marx, a propriedade privada já se encontra abolida para nove décimos da população. (MARX, 2020). Para os trabalhadores, portanto, responsáveis pela produção de todas as riquezas, coloca-se a necessidade de passar da condição de classe em si, conquistar a consciência de seu pertencimento à classe trabalhadora e serem consequentes em relação a essa condição.

Como nem a pandemia do coronavírus nem a do capital respeita fronteiras; como os capitalistas se revelam como se fossem um só quando se trata de enfrentar, atacar e espoliar os trabalhadores; como a globalização do capital é a grande responsável pela globalização do coronavírus, para enfrentar estas e outras pandemias produzidas ou potencializadas pelo capital, tais como a da fome, da violência, da miséria moral e intelectual, da desigualdade social, dentre outras, também é necessário um antídoto 
adequado: a unidade dos trabalhadores enquanto classe em escala global, o internacionalismo proletário.

Como dissemos é um absurdo discutir se a economia está acima da vida ou a vida acima da economia. Afinal, de que serve a "economia" se não tiver vida? E como se pode viver se não tiver produção? Ou seja, tratase de uma discussão oca e absurda. Na verdade, não é essa a discussão.

Sob essa nevoa de fumaça, na atual sociedade de classes, de tipo capitalista, o que se pretende esconder é que o capital, a "economia", estão acima da vida. Dane-se a vida, "é o preço a pagar em nome do Iucro", dizem. Desse modo, legitima-se o fato de que apenas oito pessoas, as mais ricas do mundo, detenham mais riquezas do que a metade da população do planeta.

Mas, é possível se fazer, pensar, produzir, se organizar de modo diferente e colocar a vida em primeiro lugar, ou então, colocar a economia a serviço da vida? Sim, não há dúvida. Contudo, para isso, supõe a luta pela transformação da sociedade existente. Afinal, não é possível se fazer omelete sem quebrar os ovos, não é mesmo? Então, como fazer diante de possíveis ameaças, de epidemias, pandemias, catástrofes, etc? Não resta dúvida de que, nesses casos, deve-se tomar todas as precauções, utilizar todos os conhecimentos, tecnologias e instrumentos já disponíveis para assegurar e proteger a vida (de todos).

Mesmo nessa sociedade, durante a pandemia, ainda que de forma artificial, presenciamos exemplos de ações solidárias e coletivas. Essas ações, porém, praticamente se limiam aos momentos de crise, como a imposta pelo coronavírus, não são expressões do ser social, de uma prática social solidária, coletiva e cotidiana. Contudo, seja se reunindo para distribuir alimentos às pessoas e famílias carentes, seja permanecendo em casa para evitar o contágio e disseminar a doença para outros, revela que é possível se organizar, agir e viver de modo diferente. Na ação coletiva e solidária, a fragilidade cede lugar e se transforma numa força colossal.

Mas, em meio a tantas injustiças e desventuras, essas ações circunstanciais e artificiais, ainda que importantes, são insuficientes para 
garantir a vida e a dignidade humana. Ao contrário do capitalismo, em que o capital está cima de tudo, no socialismo e no comunismo, a coletividade e o interesse comum estão acima de tudo, pois, defendem que a vida de cada um depende da vida do outro, em consonância com o princípio "de cada um segundo suas possibilidades, de acordo com suas necessidades".

Imagine como seria se vivêssemos em uma sociedade em que o interesse coletivo prevalecesse e a defesa da vida fosse uma preocupação de todos. Certamente não estaríamos discutindo se a economia ou a vida é mais importante. E em caso de um ataque como o desfechado pelo coronavírus, que, repetimos, não faz diferenças de quem quer que seja, não haveria dúvida de que, proteger a vida de todos e de cada um, constitui-se numa condição necessária para salvar a própria vida e garantir a felicidade de todos.

Claro que na sociedade do capital isso não é possível. Os capitalistas não só exigem como praticamente obrigam os trabalhadores retornarem aos seus postos de trabalho e se exporem aos riscos de contágio por conta e risco próprios. Não se responsabilizam pela vida do trabalhador. No entanto, já que são forçados a isso, independente dos riscos a que são submetidos, os empresários deveriam arcar com os eventuais danos causados a eles por possíveis contágios e inclusive ressarcir os cofres públicos pelas custas hospitalares e indenizar as famílias em caso de morte, ainda que, nenhuma indenização substitua, compense e valha a vida.

Ao contrário, na sociedade socialista e comunista é perfeitamente possível combinar a economia com a vida. Não se discute se, diante de uma pandemia como a que enfrentamos, é necessário manter os serviços essenciais funcionando. É evidente que sim. Afinal, a vida depende disso. Mas, manter $\mathrm{O}$ isolamento social, também é imprescindível para evitar $\mathrm{O}$ contágio, impedir a propagação da doença e preservar vidas. Do mesmo modo é imperioso que o governo banque os salários e garanta as condições de vida dos demais trabalhadores que sempre se dedicaram à produção da vida social coletiva. 
Então, como combinar simultaneamente a defesa da economia e a defesa da vida? Ressalte-se que nos encontramos no momento, como lembramos, em que o conhecimento, a ciência e a tecnologia se encontram em seu máximo grau de desenvolvimento. Por isso, enquanto determinadas pessoas e ou segmentos sociais mantém $O$ isolamento, impedem a propagação da doença e aliviam a pressão sobre o sistema de saúde e, consequentemente, não sobrecarregam os profissionais diretamente envolvidos no combate a ela e impedir que corram risco, tanto para blindar esses profissionais, como para proteger e afiançar a vida de quem necessita trabalhar em outras frentes para garantir o sustento e as condições de vida de todos, deve-se fazer uso dos melhores recursos disponíveis para protegê-los.

Veja que a discussão sobre a prioridade da economia ou da vida, é uma discussão absurda, que cabe somente na sociedade capitalista. Seria tão fácil acabar com o vírus que se apresenta tão temível se vivêssemos em um modo de produção em que a vida realmente estivesse em primeiro lugar. Inclusive, a "louvável" preocupação de "salvar a economia para salvar a vida" estaria resolvida, pois, como o vírus não sobrevive sem o hospedeiro, caso promovêssemos um isolamento social radical e utilizássemos os melhores conhecimentos, equipamentos e tecnologias para proteger os profissionais que lutam diretamente contra ele e combatem a pandemia, em não mais do que alguns dias, com baixíssimo custo econômico e poucas perdas humanas, o vírus simplesmente seria debelado, a vida protegida e a economia poderia voltar a funcionar a todo vapor, não é mesmo?

Isso, porém, pressupõe que se supere o individualismo, a competição, a concorrência, e se pense de modo solidário, na forma de "um por todos e todos por um". Ademais, o coronavírus reforçou ainda mais a necessidade do internacionalismo proletário, que Marx e Engels já defendiam a mais de 170 anos, mais precisamente, em 1848. No entanto, a exortação "Proletários do mundo, uni-vos!", nunca foi tão válida quanto hoje. 
Seja em função dos ataques dos capitalistas, das catástrofes e calamidades naturais, ou em decorrência das pragas e doenças que, em função das conexões, deslocamentos e intercâmbios globais, facilitam sua propagação e potencializam o poder de ameaça, a união dos trabalhadores é indispensável para garantir a vida. O próprio vírus e sua disseminação demostram o quanto a vida se encontra ameaçada e quanto cada um depende do outro, e de todos?.

Entretanto, por sua natureza predatória e concentradora de capital, o capitalismo não só se mostra incapaz como não pode resolver os problemas e as contradições sociais e humanas. Pois vive delas e se locupleta com elas. Ou seja, não há alternativa por dentro da sociedade do capital.

Dada a sociedade de classes, a burguesia fará tudo o que for possível e se utilizará de todos os meios para impedir a transformação social e manter seus privilégios. Mesmo que, para isso, tenha que adotar medidas autofágicas, suicidas e promover a necroeconomia.

Isso faz parte da lógica do modo de produção capitalista e sua prática predatória e destrutiva, seja em relação à natureza ou às pessoas. Portanto, não adianta nem culpabilizar os indivíduos pelo que fazem, nem achar que, para mudar a sociedade, superar as desigualdades e acabar com as injustiças, é suficiente, como defendem os moralistas e positivistas, que os indivíduos se comportem e ajam de modo diferente.

Alguns capitalistas, por exemplo, sensibilizados com as causas sociais ou com os mais vulneráveis, diante de uma situação de crise social profunda como a decorrente de grandes catástrofes "naturais" ou de pandemias, podem até "ser bons" e realizarem "obras de caridade", mas não deixarão de explorar e extrair a mais valia de seus funcionários, dos trabalhadores, dos "colaboradores".

\footnotetext{
9 Louvável o exemplo da China, onde apareceram os primeiros casos do coronavírus. Depois de bastante controlada a doença, passou a ajudar mais de 80 países ao redor do mundo com o intuito de fazerem o mesmo, afinal, dadas as conexões globais, de nada adianta controlar o vírus internamente e importar inúmeros casos contagiando seus cidadãos. Como diz o provérbio popular, seria o mesmo que "fazer um buraco na água". O mesmo ocorre com Cuba, uma pequena ilha no caribe, que a despeito do bloqueio econômico imposto pelos Estados Unidos, ao invés de enviar tanques, exércitos e bombas para destruir outros países, envia seu exército de profissionais da educação e da saúde para salvar vidas.
} 
O mesmo ocorre com a mulher, o negro, o homosexual, etc. Todos sofrem violência por sua condição e lutam pela sua libertação. Entretanto, no caso de serem empresários, independente da violência que sofrem em função de sua condição, independente de seus sentimentos e de sua vontade, obrigam-se a explorar seus iguais enquanto empregados.

Isso significa que, como nos diz Marx (1977, p. 24),

$\mathrm{Na}$ produção social da sua vida os seres humanos estabelecem determinadas relações, necessárias, independentes da sua vontade, relações de produção, que correspondem a determinado grau de desenvolvimento das suas forças produtivas materiais.

Portanto, se as relações que estabelecem não dependem da vontade individual de cada um, significa que, se quisermos acabar com esses problemas, é necessário realizar uma mudança social profunda e transformar o modo de produção social.

Iván Mészáros adverte: o capitalismo é "incorrigível" e "irreformável". (2007, p. 27). Logo, tal como defende a Pedagogia Histórico-Crítica, cabe

lutar incansavelmente pela superação do atual modo de produção, pela construção de outro que permita "produzir, direta e intencionalmente, em cada indivíduo singular, a humanidade que é produzida histórica e coletivamente pelo conjunto dos homens". (SAVIANI, 1991, p. 20-30).

A PHC não é apenas uma simples teoria pedagógica, trata-se de uma proposta de educação para um projeto de sociedade. Assume um compromisso explícito com a transformação da sociedade.

É bom lembrar que na pedagogia histórico-crítica a questão educacional é sempre referida ao problema do desenvolvimento social e das classes. A vinculação entre interesses populares e educação é explícita. Os defensores da proposta desejam a transformação da sociedade. Se este marco não está presente, não é da pedagogia histórico-crítica que se trata. (SAVIANI, 2013, p.72).

Enfim, a transformação a que se propõe a Pedagogia Histórico-Crítica diz respeito à articulação entre educação e sociedade, objetiva a identificação dos problemas postos pela prática social, sejam eles, no âmbito da educação, da saúde, da cultura, do meio ambiente, da 
produção material, das relações humanas, bem como, identificar as condições e os meios necessários à superação dos mesmos, tendo em vista a construção de uma sociedade igualitária, solidária, e, consequentemente, a felicidade de todos.

\section{Referências bibliográficas}

AGÊNCIA BRASIL. Desemprego, evasão e inadimplência preocupam faculdades privadas. Disponível em:

<https://agenciabrasil.ebc.com.br/educacao/noticia/2020-04/desempregoevasao-e-inadimplencia-preocupam-faculdades-privadas>. Acesso em: 22.04.2020.

ASSIS, Joana e MORENO, Carolina. Estudo mostra que $66 \%$ de mortos por Covid-19 na Grande SP ganhavam menos de 3 salários mínimos. Disponível em: <https://g1.globo.com/sp/sao-paulo/noticia/2020/06/16/estudo-mostraque-66percent-de-mortos-por-covid-19-na-grande-sp-ganhavam-menos-de3-salarios-minimos.ghtml>. Acesso em:17.06.2020.

AZEVEDO, R. Presidente do BB quer fim da quarentena. Disponível em: <https://noticias.uol.com.br/colunas/reinaldoazevedo/2020/03/26/presidente-do-bb-quer-fim-da-quarentena-diz-vidanao-tem-valor-infinito.htm>. Acesso em: 16.04.2020.

BARROS, Roque S. M. de. Roque Spencer e a História das ideias no Brasil. Entrevista concedida a Benedito Ferri de Barros e publicada no Jornal da Tarde. 11/04/87.

BATISTA, E. e ORSO, P. J. Capitalismo, trabalho e educação em tempos de devastação neoliberal. Marilia-SP: Lutas anticapital, 2019.

BBC.NEWS.BRASIL. A cientista que descobriu o primeiro coronavírus humano após ter abandonado escola aos 16 anos. Disponível em:

<https://www.bbc.com/portuguese/geral-52303032>. Acesso em: 18.04.2020.

BRASIL247. Presidente do Banco Central diz que reduzir mortes por Covid-19 é pior para a economia. Disponível em:

<https://www.brasil247.com/economia/presidente-do-banco-central-dizque-reduzir-mortes-por-covid-19-e-pior-para-a-

economia?fbclid=IWAR2pv1XnRwrqvp6ZcjdCUyaHa5P8ITUDGwLXaHI_6SCsSSrjKsatbEzANo>. Acesso em: 16.04.2020.

BRASIL247. Nelson Teich agora critica compra de "grande quantidade" de respiradores: "O que você fará com eles depois?". Disponível em:

<https://www.brasil247.com/brasil/nelson-teich-agora-critica-compra-de- 
grande-quantidade-de-respiradores-o-que-voce-vai-fazer-com-eles-depois> . Acesso em: 18.04.2020.

BRASIL DE FATO. "Passar a boiada": política ambiental de Bolsonaro é alvo de ações na Justiça. Disponível em:

<https://www.brasildefato.com.br/2020/06/05/passar-a-boiada-politicaambiental-de-bolsonaro-e-alvo-de-acoes-na-justica>. Acesso em: 08.06.2020.

CAPELATO, Maria Helena \& PRADO, Maria Lígia. O bravo matutino. Imprensa e ideologia: o jornal O Estado de S. Paulo. São Paulo: Alfa-Omega, 1980, p. 55.

COMTE, Augusto. Discurso sobre o espírito positivo. Trad. Renato Barboza Rodrigues Pereira. Porto Alegre: Globo; São Paulo: Edusp, 1976.

CONDORCET. Cinq mémories sur l'instrutiones publique. Paris: Flammarion, 1994.

FOLHA DE SÃO PAULO. Justus explica áudio em que chama novo coronavírus de 'gripezinha'. Disponível em: <https://telepadi.folha.uol.com.br/justusexplica-audio-seu-sobre-ressalvas-a-quarentena-pelo-coronavirus/>. Acesso em: 18.04.2020.

GAZETA DO POVO. Desigualdade de renda nos EUA é a mais alta da história.

Disponível em:

<https://www.gazetadopovo.com.br/economia/breves/desigualdade-derenda-nos-eua-mais-alta-da-historia/>. Acesso em: 15.04.2020.

G1. Câmara aprova medida provisória do Contrato Verde e Amarelo.

Disponível em: <https://gl globo.com/politica/noticia/2020/04/14/camaraaprova-medida-provisoria-do-contrato-verde-e-amarelo.ghtml>. Acesso em: 16.04.2020.

GUARESCHI, Pedrinho. Sociologia Crítica: alternativas de mudança. $6^{a}$ edição, Porto Alegre, 1986.

ISTO É. Mundo. Novo coronavírus é 10 vezes mais letal que H1N1, diz OMS. Disponível em: <https://istoe.com.br/novo-coronavirus-e-10-vezes-mais-letalque-hln1-diz-oms/>. Acesso em: 14.04.2020.

LIMA, M.R.; BATISTA, E.L. A pedagogia histórico-crítica como teoria pedagógica transformadora. In: MARSIGLIA, Ana Carolina Galvão; BATISTA, Eraldo Leme [orgs.]. Pedagogia histórico-crítica desafios e perspectivas para uma educação transformadora. 1.ed. Campinas: Autores associados, 2012, p. $1-36$.

MADEIRO, Carlos. Empresário sugere "dar tiro" no governador de AL para encerrar isolamento. Disponível em:

<https://noticias.uol.com.br/cotidiano/ultimas- 
noticias/2020/04/18/empresario-sugere-dar-tiro-no-governador-de-al-paraencerrar-isolamento.htm>. Acesso em: 18.04.2020.

MARX, K e ENGELS, F. A Ideologia Alemã. Lisboa: Edições Avante, 1981.

MARX, K. O Capital. Rio de Janeiro, Civilização Brasileira, livro 1, 1968.

MARX, K. Contribuição à crítica da economia política. São Paulo: Martins Fontes, 1977.

MARX, K. Manuscritos Econômico-Filosóficos. Disponível em:

<https://www.marxists.org/portugues/marx/1844/manuscritos/cap01.htm>. Acesso em: 14.04.2020.

MARX, K. O 18 Brumário de Louis Bonaparte. Disponível em:

<https://www.marxists.org/portugues/marx/1852/brumario/cap01.htm>. Acesso em: 15.04.2020.

MILITÃO, Eduardo e ARAÚJO, Carla. Bancos elogiam austeridade fiscal de Guedes em reunião ministerial. Disponível em:

<https://economia.uol.com.br/noticias/redacao/2020/05/23/bancosempresarios-reuniao-ministerial-austeridade-fiscal-paulo-guedes.htm>. Acesso em: 23.05.2020.

NAIME, Laura. Desemprego sobe para $12,4 \%$ em fevereiro, diz IBGE. Disponível em:

<https://gl.globo.com/economia/noticia/2019/03/29/desemprego-sobepara-124percent-em-fevereiro-diz-ibge.ghtml>. Acesso em: 20.04.2020.

NASCIMENTO, Terezinha A. Q. Ribeiro. Pedagogia conservadora liberal modernizadora. Campinas -SP: Autores Associados-FE/Unicamp, 1997.

OLIVEIRA, Francisco de. Prefácio: A face do horror. Silva Jr., João dos Reis; Sguissardi, Valdemar. Novas faces da educação superior no Brasil: reforma do Estado e mudança na produção. Uberlândia: Navegando Publicações, 2020.

ORSO, Paulino José. Liberalismo, neoliberalismo e educação. Roque Spencer Maciel de Barros, um ideólogo da burguesia brasileira. Campinas: Unicamp, Faculdade de Educação, 2003. Tese de doutorado.

ORSO, Paulino José. Pedagogia Histórico-Crítica no campo. In: BASSO, J. D.; NETO, J. L. dos S.; BEZERRA, M. C. dos S. (Orgs). Pedagogia Histórico-Crítica e educação no campo: história, desafios e perspectivas atuais. São Carlos: Pedro \& João Editores e Navegando, 2016.

ORSO, Paulino José. Pedagogia Histórico-Crítica: uma teoria pedagógica revolucionária. In. Pedagogia Histórico-Crítica: revolução e formação de 
professores. DUARTE DE MATOS, Neide, ARUDA DE SOUZA, Joceli de Fátima e SILVA, João Carlos. Campinas-SP: Armazém do Ipê, 2018.

ORSO, P. J. Educação e lutas de classes: concepções e propostas pedagógicas. In.:

ORSO, P. J. Escola "sem" Partido ou um partido a serviço da burguesia? In. BATISTA, Eraldo Leme, ORSO, Paulino José e LUCENA, Carlos. Escola sem partido ou a escola da mordaça e do partido único a serviço do capital. Uberlândia: Navegando Publicações, 2019. Disponível em: <https://56e818b22c0c-44d 1-8359-

ccl62f8a5934.filesusr.com/ugd/35e7c6_d8896227fb2d4b739df2f1 18829486b9. $\mathrm{pdf}>$.

ORSO, P. J. As possibilidades e limites da educação na sociedade de classes. Disponível em: <https://histedbrnovo.fe.unicamp.br/pfhistedbr/seminario/seminario9/PDFs/6.10.pdf>. Acesso em: 17.04.2020a.

ORSO, P. J. Educação em tempos de golpe, ou como avançar andando para trás. Disponível em: <file:///C:/Users/Usuario/Downloads/21735-76394-1PB.pdf>. Acesso em: 15.04.2020b.

OXFAM, Brasil. Coronavírus vai empurrar meio bilhão de pessoas para a pobreza. Disponível em: <https://oxfam.org.br/noticias/coronavirus-vaiempurrar-meio-bilhao-de-pessoas-para-a-pobreza/>. Acesso em: 15.04.2020.

PT. Assessora do governo defende que mortes por Covid-19 "se concentrem em idosos". Disponível em: <https://pt.org.br/assessora-do-governo-defendeque-mortes-por-covid-19-se-concentrem-em-idosos/>. Acesso em: 27.05.2020.

SAVIANI, Demerval. Educação: do senso comum à consciência filosófica. São Paulo: Cortez; Autores Associados, 1980.

SAVIANI, Demerval. Escola e Democracia. $1^{a}$ edição, São Paulo: Cortez editora e Autores Associados, 1983.

SAVIANI, Demerval. Escola e Democracia. Edição Comemorativa. Edição Comemorativa. Campinas: Autores Associados, 2008.

SAVIANI, Demerval. Pedagogia Histórico-Crítica: primeiras aproximações. 11.ed. Campinas: Autores Associados, 2013.

SAVIANI, Dermeval; DUARTE, Newton. Prefácio. In: SAVIANI, D.; DUARTE, N. (orgs.) Pedagogia histórico-crítica e luta de classes na educação escolar. Campinas: Autores Associados, 2012.

SIMONARD, Pedro. "Nós já botamos a granada no bolso do inimigo: dois anos sem aumento de salário" - a mentira como estratégia de governo.

Disponível em: <https://www.brasil247.com/blog/nos-ja-botamos-a-granada- 
no-bolso-do-inimigo-dois-anos-sem-aumento-de-salario-a-mentira-comoestrategia-de-governo>. Acesso em: 08.06.2020.

UOL. Economia. Madero, Havan, Giraffas: empresários criticam medidas de combate à pandemia. Disponível em:

<https://economia.vol.com.br/noticias/redacao/2020/03/24/empresarioscoronavirus-o-que-dizem-criticas.htm>. Acesso em: 16.04.2020.

UOL. Economia. OIT: mais da metade dos trabalhadores podem perder meios de subsistência. Disponível em:

<https://economia.vol.com.br/noticias/afp/2020/04/29/oit-mais-da-metadedos-trabalhadores-podem-perder-meios-de-subsistencia.htm>. Acesso em: 28.04.2020.

URIBE, Gustavo. Ministro do Meio Ambiente defende aproveitar crise do coronavírus para 'passar a boiada'. Disponível em:

<https://wwwl.folha.vol.com.br/ambiente/2020/05/ministro-do-meioambiente-defende-aproveitar-crise-do-coronavirus-para-passar-aboiada.shtml>. Acesso em: 23.05.2020.

VALENTE, Rubens. Novo ministro já propôs escolha entre jovem e idoso "no final da vida". Disponível em: <https://noticias.uol.com.br/colunas/rubensvalente/2020/04/16/mandetta-coronavirus-saude.htm>. Acesso em: 18.04.2020.

Recebido em: 07 de junho de 2020 Aprovado em: 20 de julho de 2020 Publicado em: 24 de julho de 2020 